\title{
UPTAKE OF DIFFERENT DYES BY TWO NEW STRAINS OF MICROALGAL DRY BIOMASS
}

\author{
P. M. Abdulkareem ${ }^{1}$ \\ Assist. Lecturer \\ S. S. Anwer ${ }^{2}$ \\ Assist. Prof.
}

${ }^{1}$ Dept. Biol. Coll. Health, Sci. University Koya

${ }^{2}$ Dept. Clin. Bioch. Coll. Health, Sci. University Hawler Med.

ABSTRACT

parween.mohsin@koyauniversity.org

The control of wastewater pollution has become of increasing importance in recent years. The release of dyes into the environment constitutes only a small proportion of water pollution, but dyes are visible in small quantities due to their brilliance. In this study Spirulina subsalsa and Scenedesmus ecornis microalgae isolated from Chnarok and Taq-Taq Koya city and its ability to uptake different dyes. Batch studies were conducted at separate biosorbent doses ,dye concentration, pH, temperature and agitation speed. Optimum adsorption of dyes by Spirulina subsalsa and Scenedesmus ecornis showed in reactive yellow $(89.3 \%, 90.4 \%)$ respectively at $50 \mathrm{mg} \mathrm{l}^{-1}, 30^{\circ} \mathrm{C}, \mathrm{pH} 8,150 \mathrm{rpm}$, dosage $1.2 \mathrm{~g} \mathrm{ml}^{-1}$.

Key words: dye uptake, biosorbent, optimum removal, biosorption, environment.

عبد الكريم و انور

62-48:(1) 52:2021 مجلة العلوم الزراعية العراقية

$$
\begin{aligned}
& \text { تحديث الأصباغ المختلفة بواسطة سلالات جديدة ثنائية الكتلة الحيوية } \\
& \text { سيوكل سعدالدين انور } \\
& \text { استاذ مساعد }
\end{aligned}
$$

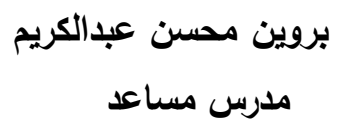

المستخلص

أصبحت السيطرة على تلوث المياه العادمة ذات أهية متزايدة في السنوات الأخيرة. لا يشكل إطلاق الأصباغ في البيئة سوى

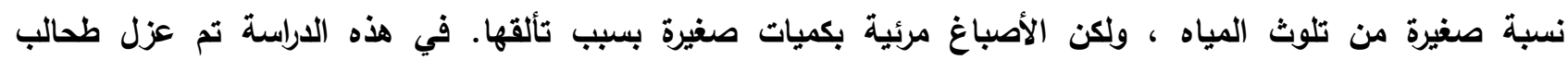
Spirulina subsalsa

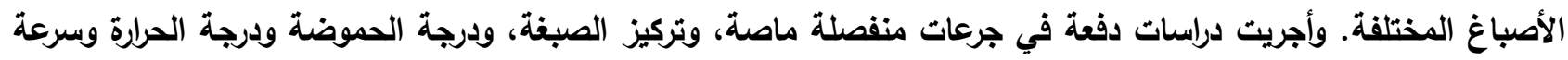
الانفعالات. أظهرت الامتزاز الأمثل للأصباغ بواسطة Scenedesmus ecornis و باللون Sactive subsalsa yellow جرعة 1.2 غرام/ مل -1) الكلمات المفتاحية: امتصاص الصبغ، الماصة الحيوية، الإزالة المثلى، الامتصاص الحيوي، البيئة. 


\section{INTRODUCTION}

Dyes are substance that adhere to substrate and colored the substrate, Dyes are toxic, mutagenic, and dangerous to aquatic living organisms (22). Dyes are used in different industries such as production of pulp and paper, leather tanning or textile dying and in manufacture of dyestuffs after application the more amount of effluents release to the environment that cause pollution and effects to water and terrestrial environments. Physicochemical method for the removal of dyes from wastewater such as coagulation and flocculation, advanced oxidation, activated carbon, ozonation and photocatalysis unable to predict the effects on the organisms in the ecosystem and sometime byproducts produce during treatment process (15). Various biomaterials such as bacteria, fungi and algae can reduce and remove industrial and agricultural pollutants in wastewater and can be utilized in purification of contaminated water by the substances such as dyes and metals that cannot be easily resolved due to their cost-effectiveness, rapid, reversible, and in several ways algae have used under different conditions to decrease environmental pollution their production of less sludge. Their eco-friendly nature has attracted interest as a valuable technology in the area of water treatment and depend on the possible interactions between pollutant and the cellular surface of the biomaterial $(10,11,14)$.Microlgae are photosynthetic organism that are the primary biomass producers and have different functional group on the biomass surface like hydroxyl, carboxyl, sulfhydryl, amino, phosphoryl, and thiol and are requires minimal preparatory steps, naturally renewable that have been suggested as ideal biosorbent for wastewater treatment systems using biosorption process $(9,12,26,27)$. This study was aimed to evaluate ability of microalgae biomass (biosorbents) to reduce different dyes.

\section{MATERIAL AND METHODS}

\section{Isolation and identification of}

microalgae:Water samples were collected from Hamamok- Koya city. Water obtained from $4 \mathrm{ml}$ depth were diluted and plated on Blue Green medium (BG11) The cultures were incubated at $\mathrm{pH} 7.8$ and $28^{\circ} \mathrm{C}$ under constant light 800Lx. Two weeks later, following the growth of colonies on the agar media, the colonies were removed with pasture micropipettes and gently blown into the liquid medium, then incubated at $28^{\circ} \mathrm{C}, 800 \mathrm{Lx}$ and $\mathrm{pH}$ 7.8. as described by $(3,23)$.

\section{Biosorption of Dyes}

Preparation of biomass: Microalgae biomass initially dried from moisture on an aluminum tray, kept in the oven at $80^{\circ} \mathrm{C}$ for 24 hours, after cooling, the samples were subjected to sieve analysis.

\section{Biosorption of dyes}

Aqueous dye solutions with the required levels were prepared from $0.2 \mathrm{~g} / 10 \mathrm{ml}$ inventory alternatives. Batch adsorption studies were conducted in $250 \mathrm{ml}$ conical flask containing $100 \mathrm{ml}$ aqueous dye solution of the required concentration and known quantity of biosorbent. Initial $\mathrm{pH}$ was adjusted to the desired level with $1 \mathrm{~N} \mathrm{NaOH}$ or $1 \mathrm{~N} \mathrm{HCl}$ solutions. The dye solution was then separated from the adsorbent by centrifugation and the dye concentration was determined by spectrophotometer, the rate of biosorption recorded by spectrophotometer $(507 \mathrm{~nm}$ for Direct red 254, $610 \mathrm{~nm}$ for Reactive Blue 214, 493, for Reactive black 5 and Reactive Yellow $410 \mathrm{~nm}$. Batch studies were conducted at separate biosorbent doses ranging from $0.3 \mathrm{~g}$ $\mathrm{ml}^{-1}, 0.6 \mathrm{~g} \mathrm{ml}^{-1}, 0.9 \mathrm{~g} \mathrm{ml}^{-1}, 1.2 \mathrm{~g} \mathrm{ml}^{-1}$ to $0.5 \mathrm{~g}^{-1}$ $\mathrm{ml}^{-1}$, original dye concentrations ranging from $25,50,75,100$ and $125 \mathrm{mg}^{-1}$ and $\mathrm{pH}$ ranging from 6.5 to 8.5 agitation speed from zero, 50, 100,150 and 200rpm temperature from 20, 25, 30,35 to $40{ }^{\circ} \mathrm{C}$ were studied. The uptake of dyes calculated using the following formula (5)
Biosorption $=[(\mathrm{Co}-\mathrm{C}) / \mathrm{Co}]^{*} 100$
$\mathrm{Co}=$ Initial Dye concentration
$\mathrm{C}=$ Final Dye concentration

The characterization techniques were done by using Infrared spectroscopy (FTIR) ( College of Education-Salahaddin University) were performed using $\mathrm{KBr}$ pellet technique in the frequency range of 4000 to $500 \mathrm{~cm}-1$ by pressing the powder of samples before and after biosorption process with $\mathrm{KBr}$ discs then subjected to spectral analysis as described by (7). 


\section{RESULT AND DISSCUSION}

Biosorption of Dyes by Spirulina subsalsa and Scenedesmus ecornis:

Effect of dye concentrations on: biosorption by Spirulina subsalsa and Scenedesmus ecornis : Biosorption of direct red 254, reactive blue 214 , reactive orange 16 , reactive black 5 and reactive yellow at different initial concentration (25-125 $\mathrm{mg} \mathrm{l}^{-1}$ ) by Scenedesmus ecornis was studied as functional of contact time. As shows in Figure 1 (a-j) optimum adsorption of all dyes by Spirulina subsalsa and Scenedesmus ecornis showed at low concentration $25 \mathrm{mgl}^{-1}$ with different contact times which varied from $84.3 \%, 82.7 \%$

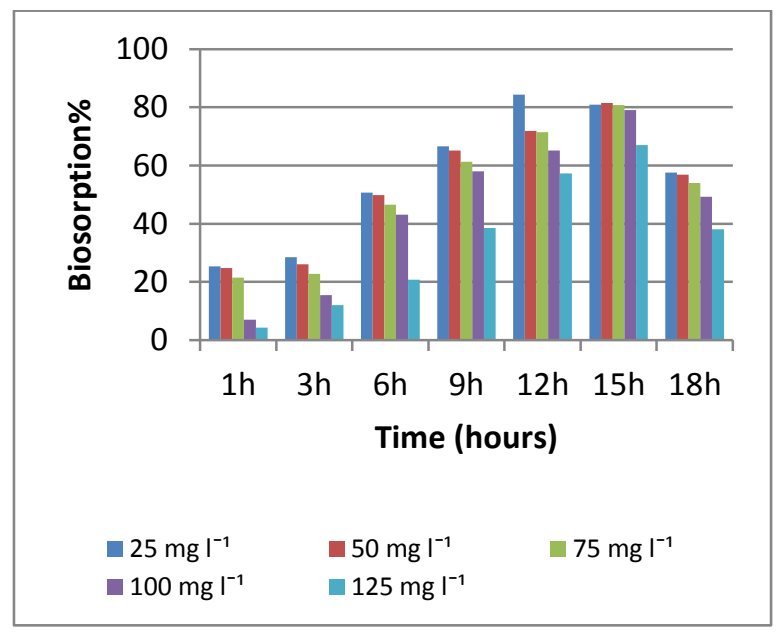

(a)

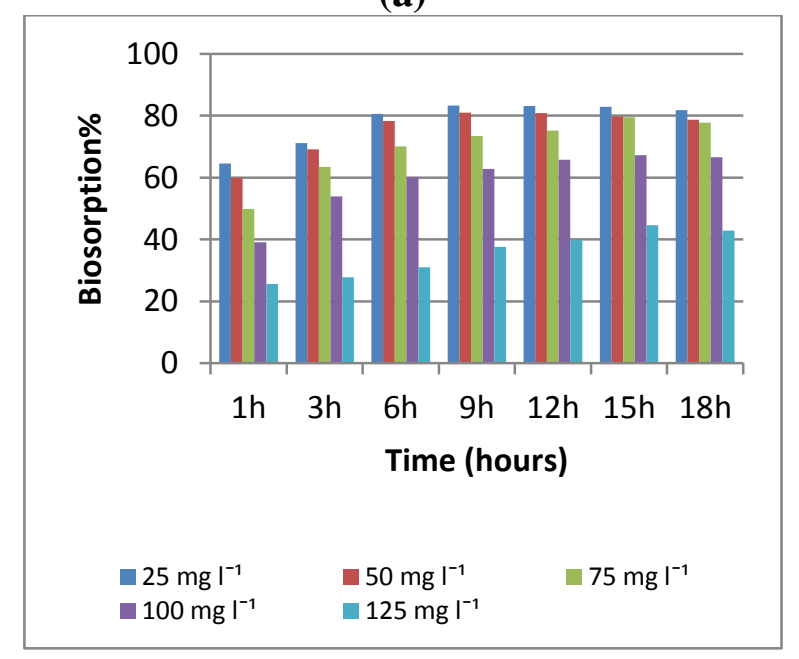

(c)
(Reactive yellow) at 12. hours, $83.3 \%, 82.5 \%$ (Reactive black 5) at 9. hours, $81.7 \%$ at 15 . hours, $79.7 \%$ at 9 . hours (Reactive Blue 214), $21.9 \%$, in Spirulina subsalsa and Scenedesmus ecornis by increase initial dye concentration, the percentage of biosorption of all dyes decreased. A similar trend was reported by $(16,24,28)$. (6) conducted that the higher removal of dyes observed at $25 \mathrm{ml}$ by Pseudomonas fluorescens. The initial rapid uptake of the dye indicates that the sorption process could be ionic in nature where the acidic (anionic) dye molecules bind to the various positively charged organic functional groups present on the surface of the biomass (17).

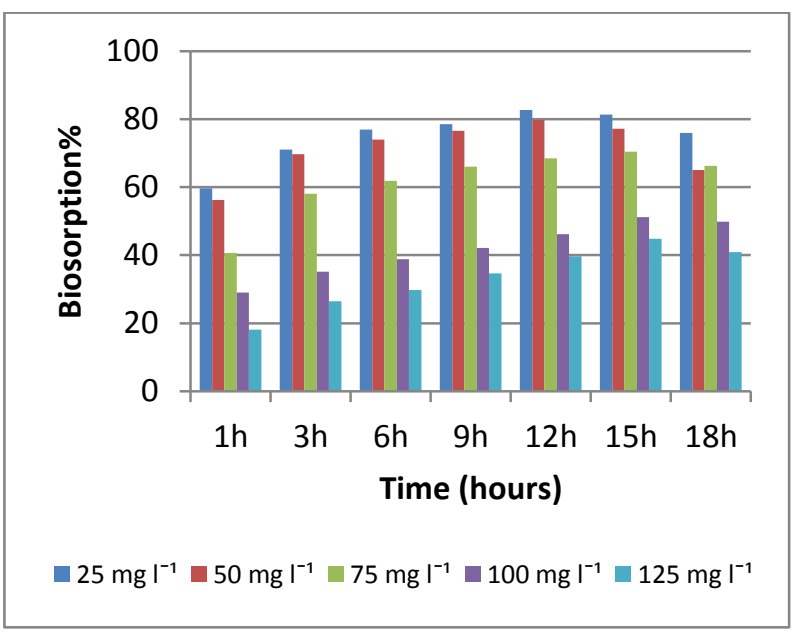

(b)

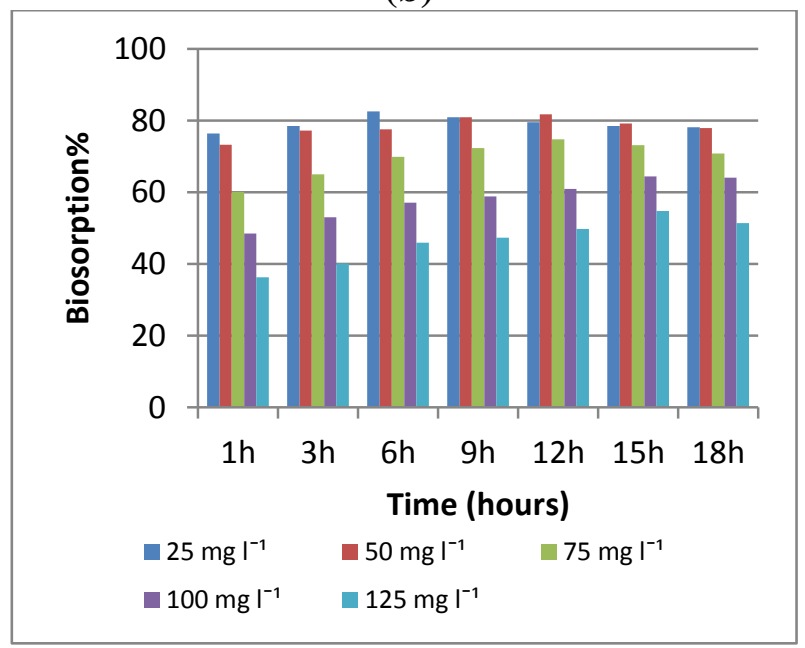

(d) 


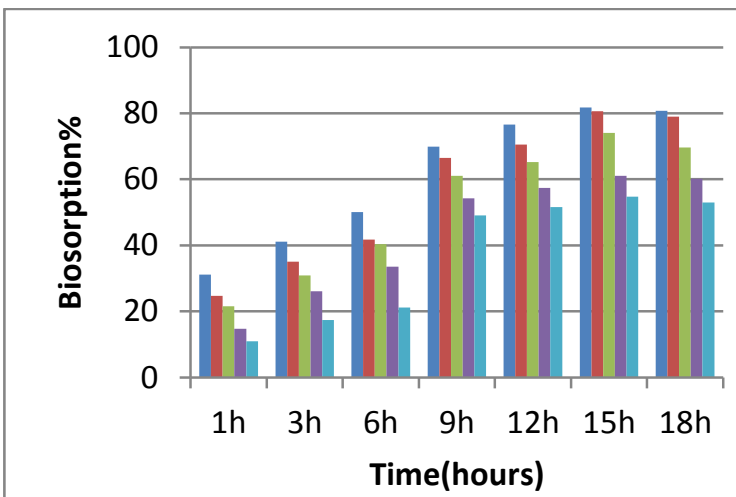

$25 \mathrm{mgl}^{-1}-50 \mathrm{mg} \mathrm{l}^{-1}-75 \mathrm{mgl}^{-1}-100 \mathrm{mgl}^{-1}-125 \mathrm{mgl}^{-1}$

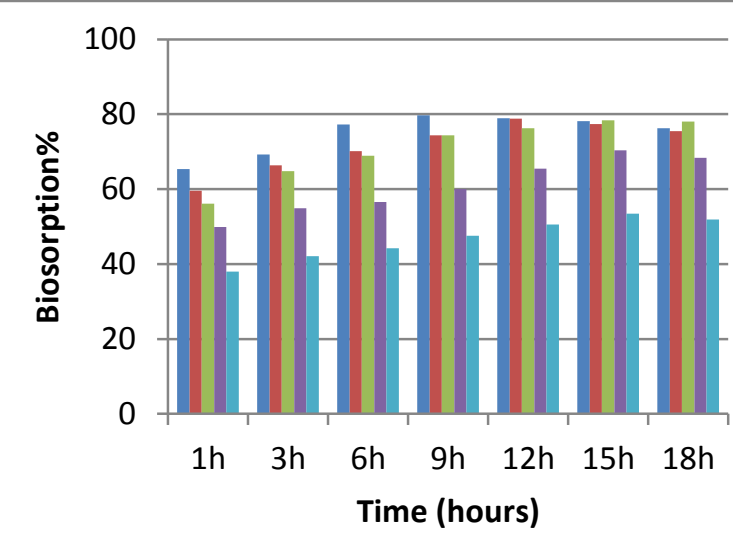

$\square 25 \mathrm{mg} \mathrm{l}^{-1}-50 \mathrm{mg} \mathrm{l}^{-1} \square 75 \mathrm{mgl}^{-1}-100 \mathrm{mgl}^{-1}-125 \mathrm{mgl}^{-1}$

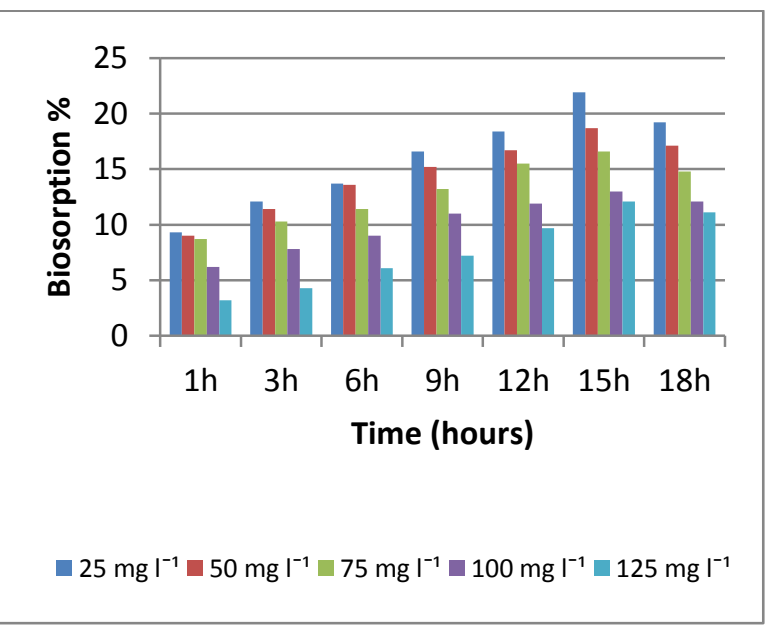

(g)

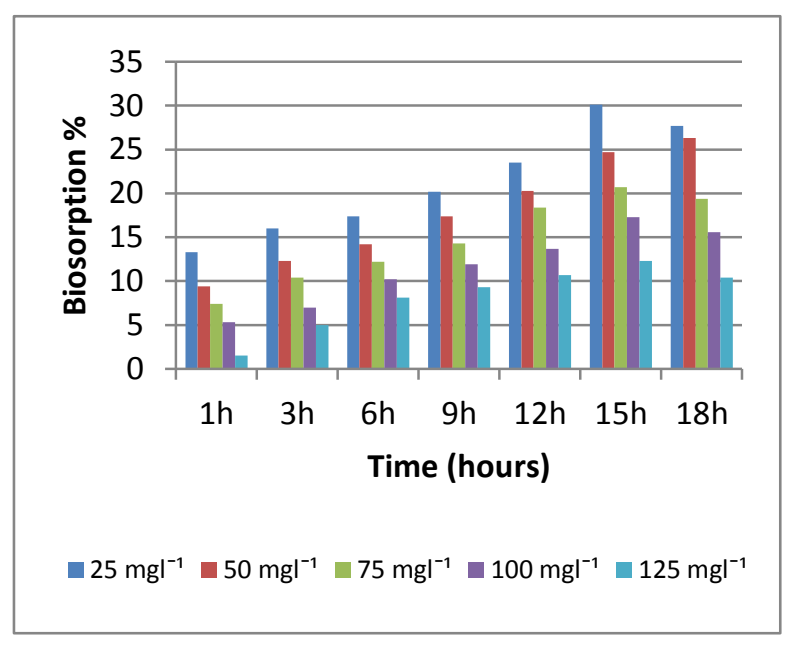

(i) (f)

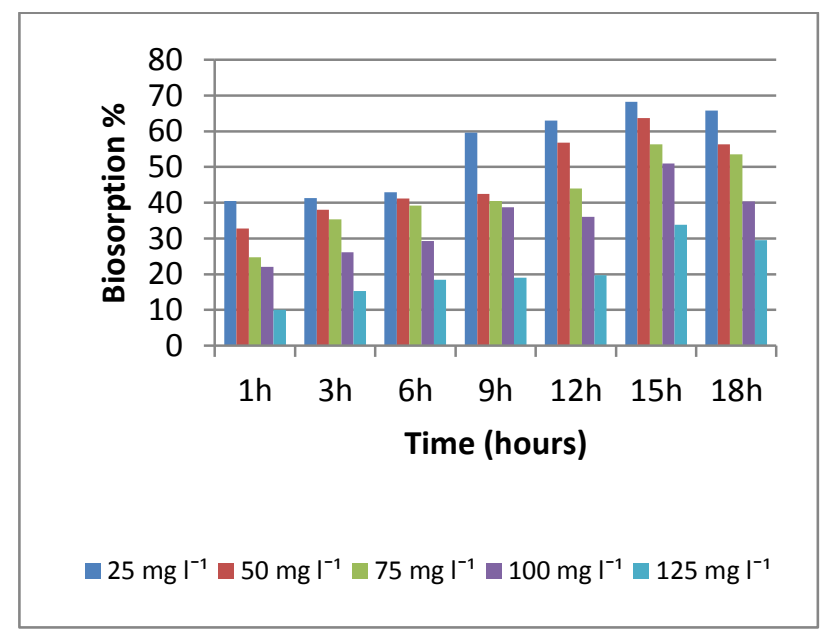

(h)

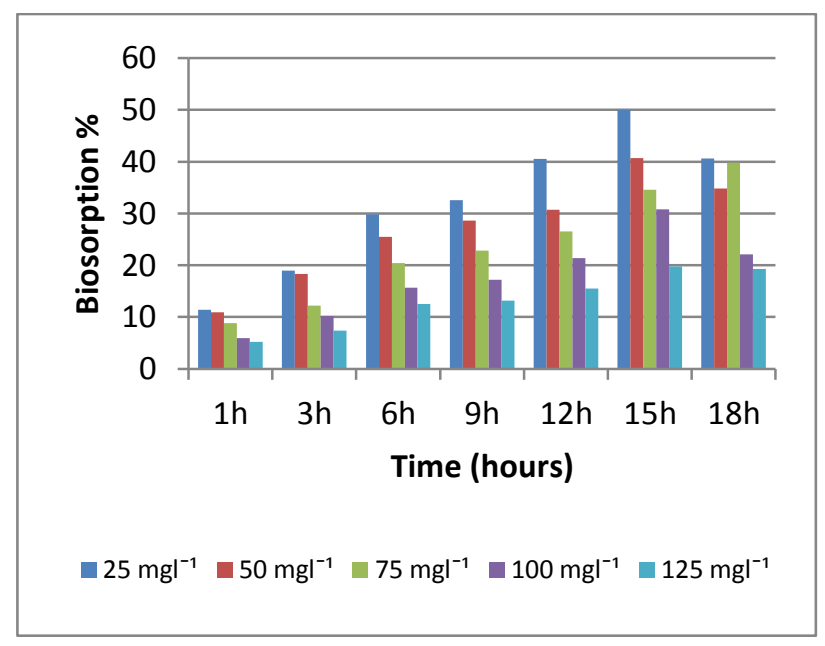

(j)

Fig. 1. Effect of [(a,b)Reactive yellow, (c,d)Reactive black 5, (e,f) Reactive Blue 214, (g,h) Reactive Orange 16, (i,j) Direct Red 254)] concentration on biosorption process $\left(\mathrm{pH} 7,35^{\circ} \mathrm{C}\right.$, 100rpm) by (a, c, e, g, i) Spirulina subsalsa and (b, d f, h, j) Scenedesmus ecornis 
Effect of temperature on biosorption of dyes by Spirulina subsalsa and Scenedesmus ecornis:The effect of different temperature $\left(20,25,30,35,40^{\circ} \mathrm{C}\right)$ on adsorption of different dyes by Spirulina subsalsa and Scenedesmus ecornis using $50 \mathrm{mg} \mathrm{l}^{-1}$ initial dye concentration shows in Figure 2 (a-j). The results indicated maximum adsorption of reactive yellow $(87.7 \%, 85.9 \%)$ at 12 hours, reactive black $5(86.5 \%$ at 12 . hours, 84.6 at 9 . hours), reactive blue 214 ( $84.5 \%$ at 12 . hours, $86.4 \%$ at 9 . hours, within the temperature

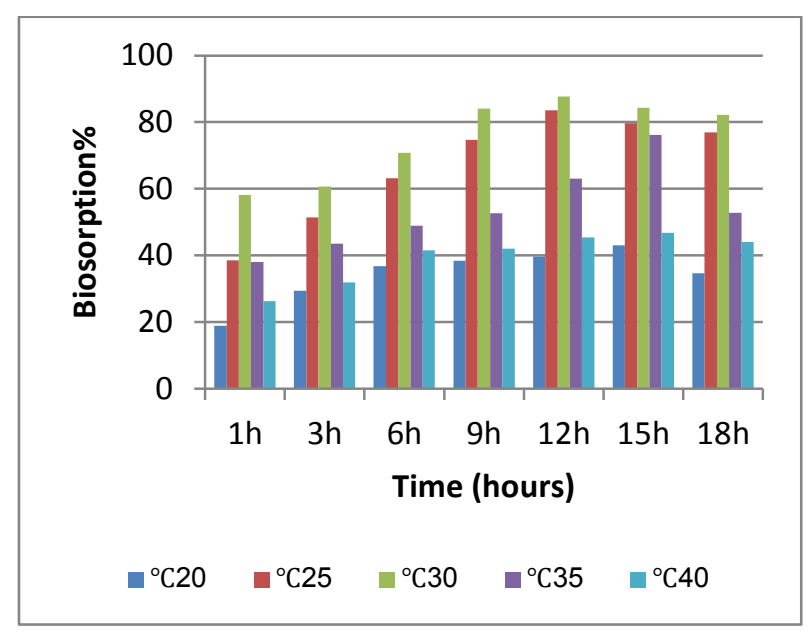

(a)

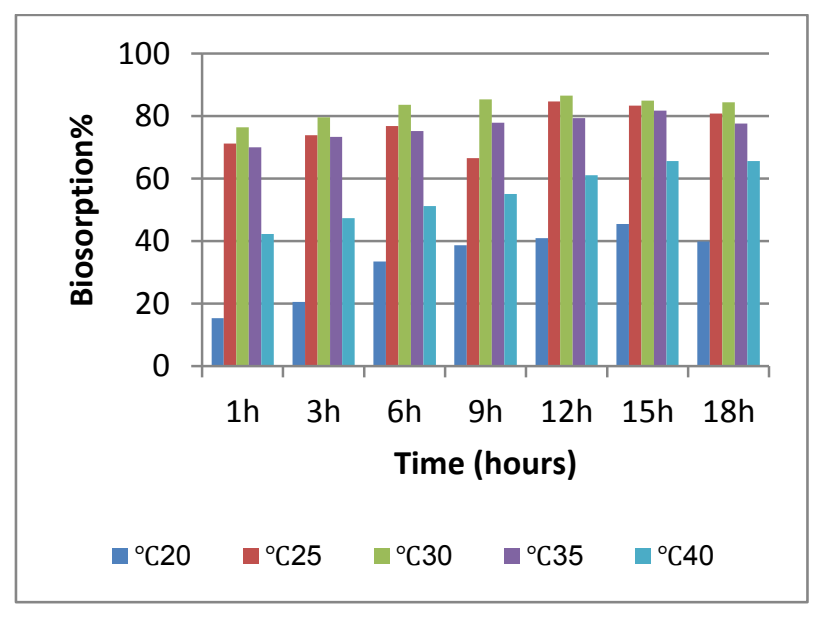

(c) $30^{\circ} \mathrm{C}$. The percentage of dye uptake was increased from 20 to $30{ }^{\circ} \mathrm{C}$ and then showed decrease in sorption percentage with further increase in temperature. Similar observation was made by (18) where they observed an increase in biosorption of Remazol Brilliant Blue R by Phanerochaete chrysosporium with increase in temperature up to $30^{\circ} \mathrm{C}$, (19) showed that the optimum dye removal for fungus and algae was at $30^{\circ} \mathrm{C}$. (6) reported that the maximum removal of different dyes by Pseudomonas fluorescens was $30^{\circ} \mathrm{C}$.

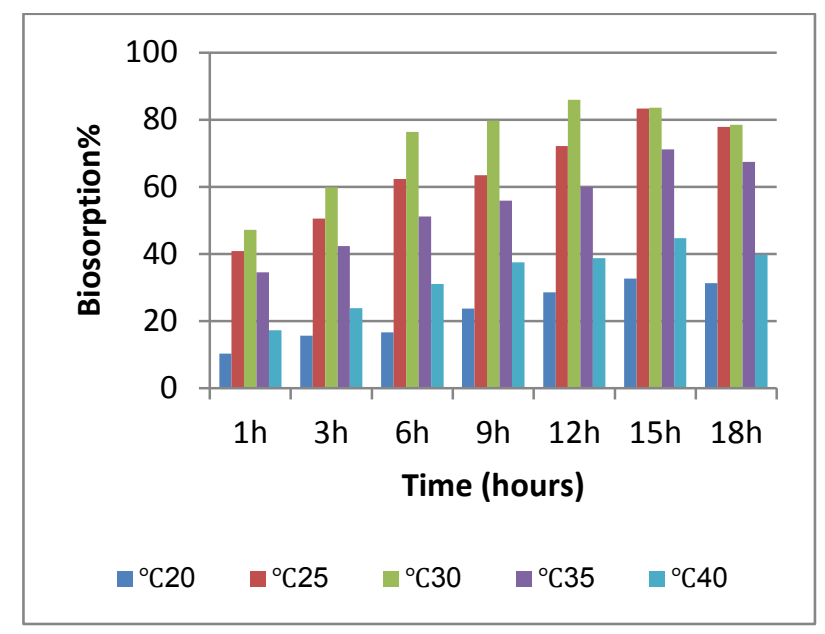

(b)

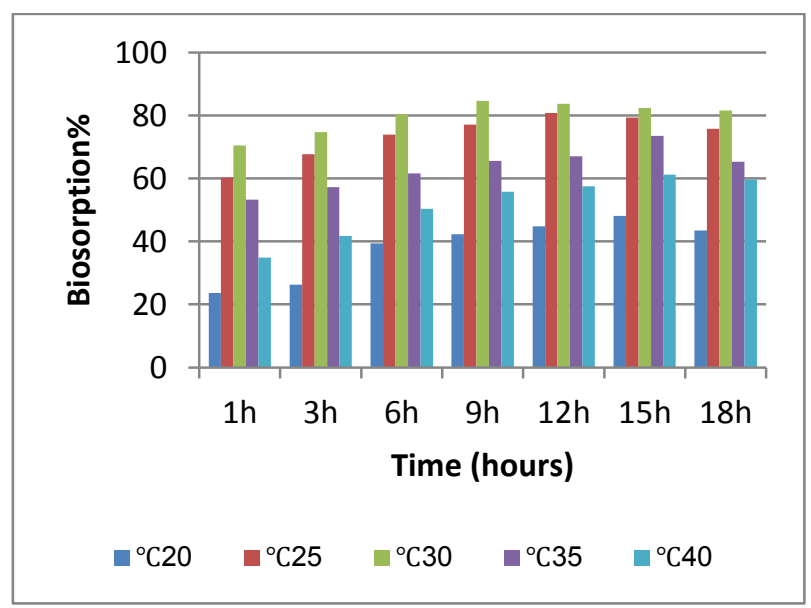

(d) 


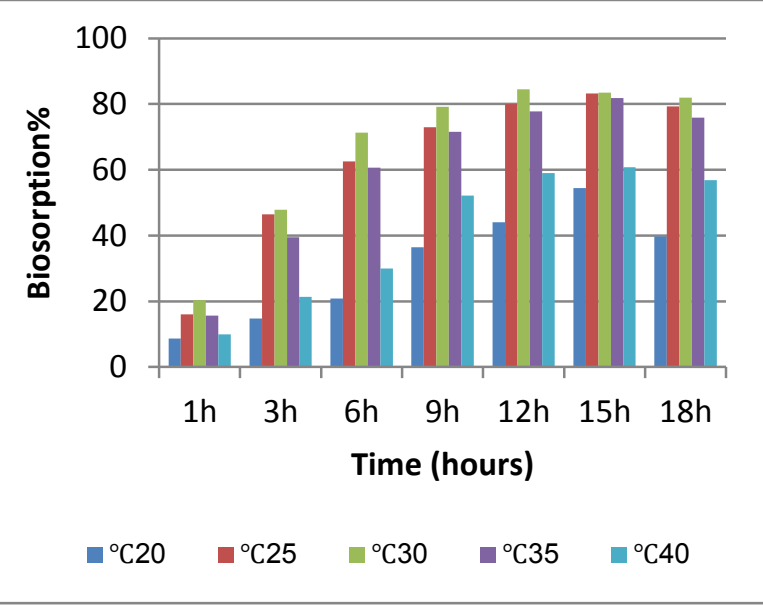

(e)

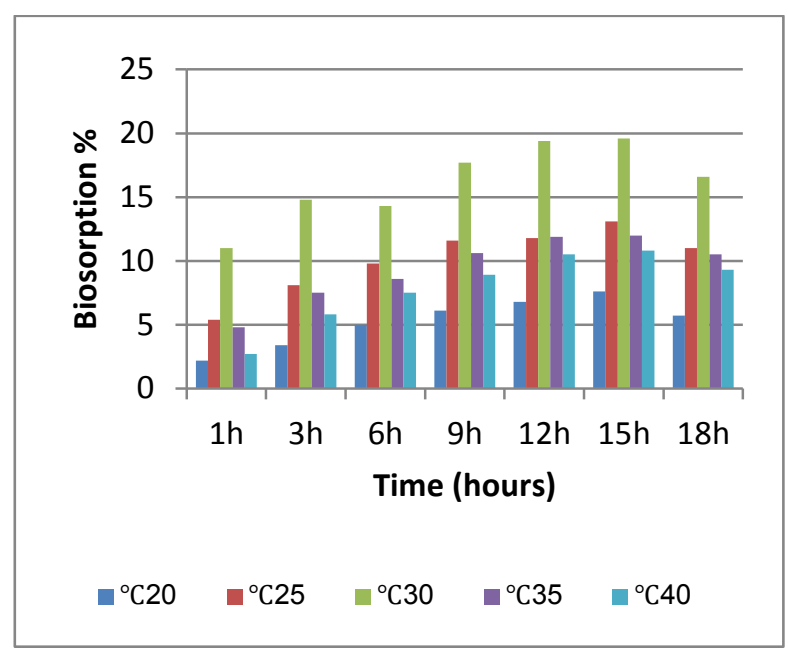

(g)

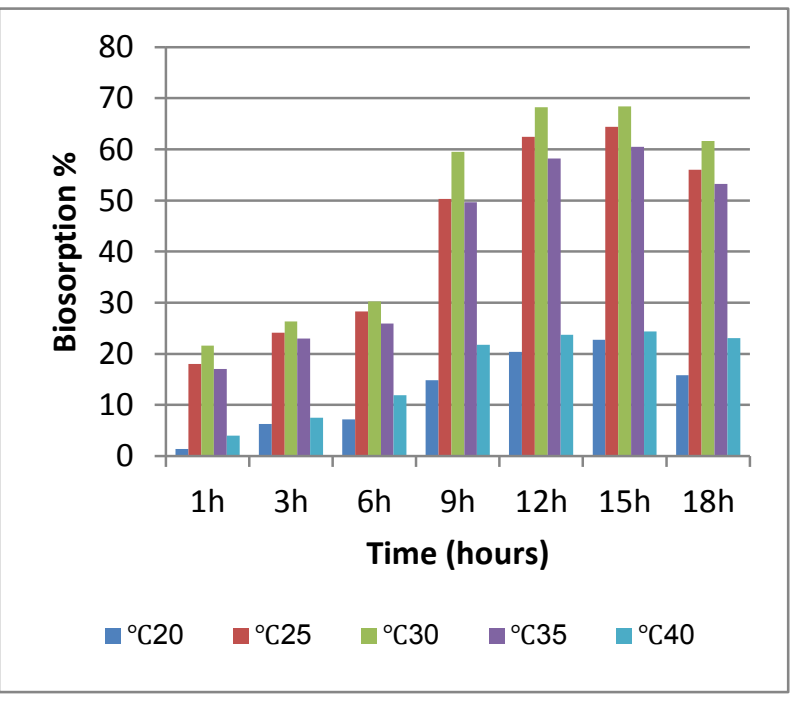

(i)

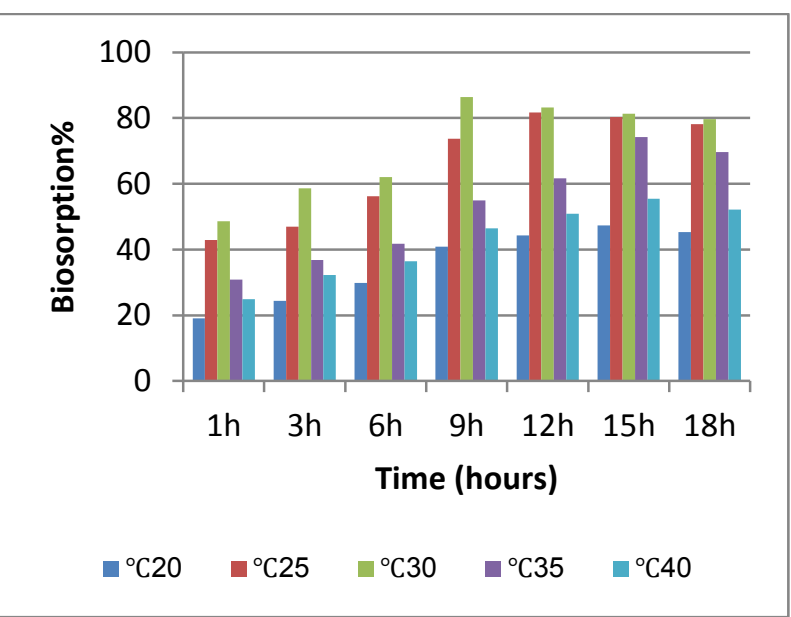

(f)

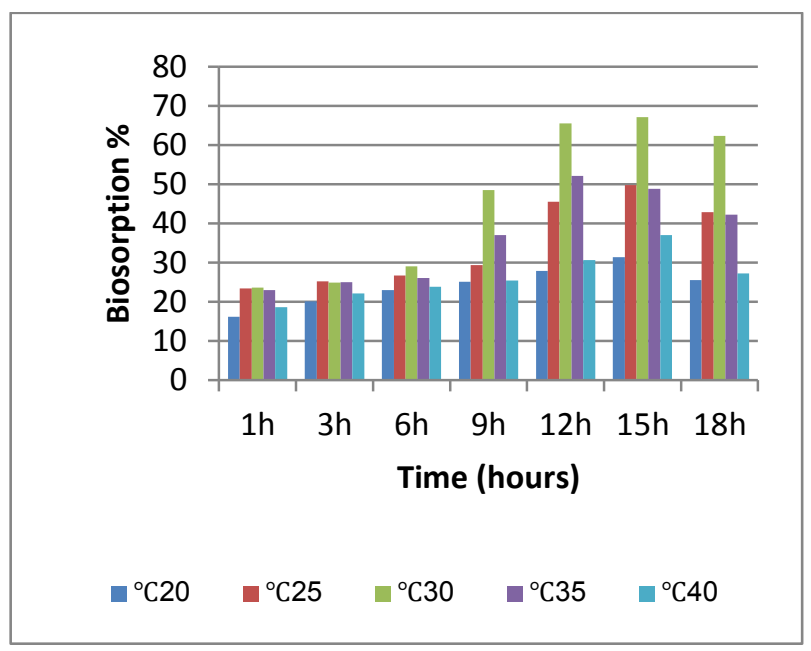

(h)

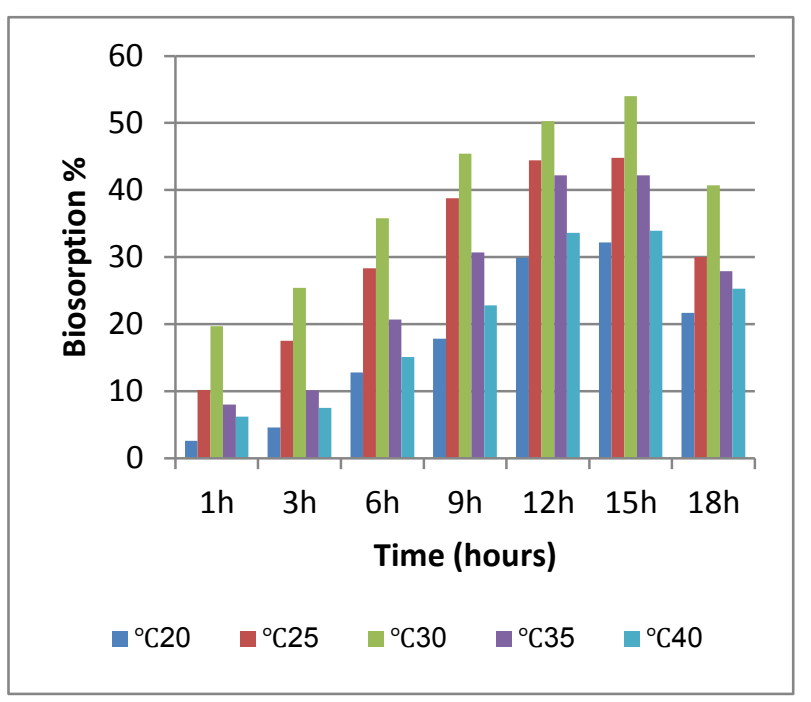

(j)

Fig. 2. Effect of temperature on [(a,b) Reactive yellow, (c,d) Reactive black 5, (e,f) reactive Blue, (g,h) Reactive Orange 16, (i,j) Direct Red 254)] adsorption 50 mgl-1, pH 7, 100 rpm (a, c, $\mathrm{e}, \mathrm{g}$, i) Spirulina subsalsa and (b, d, f, h, j) Scenedesmus ecornis 
Effect of pH on biosorption of dyes by Spirulina subsalsa and Scenedesmus ecornis potential hydrogen $(\mathrm{pH})$ is one of the important parameter of adsorption as it depends on the surface chemistry of the adsorbent and the ion state of the solution $(1,21)$. The effect of different $\mathrm{pH}$ values $(6.5$, $7,7.5,8,8.5)$ to biosorption capacity $50 \mathrm{mg}^{-1}$ initial dye concentration and $30^{\circ} \mathrm{C}$ shows in Table (1-5) the effect of $\mathrm{pH}$ on adsorption of different dye molecules by Spirulina subsalsa and Scenedesmus ecornis. It was observed that different types of dye molecules adsorbed at different $\mathrm{pH}$ by algal biomass. Dyes such as Reactive yellow, reactive black 5 , reactive
Blue 214 showed maximum adsorption at $\mathrm{pH}$ (8.5) by Spirulina sunsalsa as shows in Table $(1,2,3,5)$ and reactive orange 16 adsorbed at $\mathrm{pH}$ (8) in Table (4), while optimum adsorption of reactive yellow, reactive black 5 , by Scenedesmus ecornis was at $\mathrm{pH}$ (8) Table (1, $2,4,5)$ and reactive blue 214 at $\mathrm{pH}(8.5)$ Table (3). Biosorption of dye increased with increased $\mathrm{pH}$. A similar trend was also observed for the adsorption of dye by Cyanobacteria (5.25). The algal cell wall contains several functional groups and the adsorption is depends on the protonation or deprotonation of these functional groups (21).

Table 1. Effect of pH on biosorption of dye (reactive yellow) by Spirulina sunsalsa and Scenedesmus ecornis $\left(50 \mathrm{mg} \mathrm{l}^{-1}, 30^{\circ} \mathrm{C}, 100 \mathrm{rpm}\right)$

\begin{tabular}{|c|c|c|c|c|c|c|c|c|}
\hline \multirow[b]{2}{*}{ pH } & \multicolumn{4}{|c|}{ Spirulina subsalsa (reactive yellow) } & \multicolumn{4}{|c|}{ Scenedesmus ecornis (reactive yellow) } \\
\hline & $\mathrm{C}_{0}\left(\mathrm{mg} \mathrm{l}^{-1}\right)$ & $\begin{array}{c}\text { Time } \\
\text { (hours) }\end{array}$ & $\mathrm{CC}_{0}\left(\mathrm{mgl}^{-1}\right)$ & \% Biosorption & $\mathrm{C}_{0}\left(\mathrm{mg} \mathrm{l}^{-1}\right)$ & $\begin{array}{c}\text { Time } \\
\text { (hours) }\end{array}$ & $\mathrm{CC}_{0}\left(\mathrm{mg} \mathrm{l}^{-}\right.$ & $\%$ Biosorption \\
\hline 6.5 & 91.82 & 15h & 35.6 & 38.8 & 91.82 & 15h & 29.0 & 31.6 \\
\hline 7 & 92.52 & $15 \mathrm{~h}$ & 48.3 & 52.3 & 92.52 & $15 \mathrm{~h}$ & 41.6 & 44.9 \\
\hline 7.5 & 93.21 & 15h & 64.5 & 69.2 & 93.21 & 15h & 69.0 & 74.1 \\
\hline 8 & 94.6 & $12 \mathrm{~h}$ & 82.4 & 87.1 & 94.6 & $12 \mathrm{~h}$ & 83.3 & 88.1 \\
\hline 8.5 & 96.69 & $9 \mathrm{~h}$ & 86.4 & 89.4 & 96.69 & $12 \mathrm{~h}$ & 81.7 & 84.5 \\
\hline
\end{tabular}

Table 2. Effect of pH on biosorption of dye (reactive black 5) by Spirulina subsalsa and Scenedesmus ecornis $\left(50 \mathrm{mg} \mathrm{l}^{-1}, 30^{\circ} \mathrm{C}, 100 \mathrm{rpm}\right)$

\begin{tabular}{|c|c|c|c|c|c|c|c|c|}
\hline \multirow[b]{2}{*}{ pH } & \multicolumn{4}{|c|}{ Spirulina subsalsa (reactive black 5) } & \multicolumn{4}{|c|}{ Scenedesmus ecornis (reactive black 5) } \\
\hline & $\mathrm{C}_{0}\left(\mathrm{mg} \mathrm{l}^{-1}\right)$ & $\begin{array}{c}\text { Time } \\
\text { (hours) }\end{array}$ & $\mathrm{CC}_{0}\left(\mathrm{mgl}^{-1}\right)$ & \% Biosorption & $\mathrm{C}_{0}\left(\mathrm{mg} \mathrm{l}^{-1}\right)$ & $\begin{array}{l}\text { Time } \\
\text { (hours) }\end{array}$ & $\underset{\left.{ }_{1}\right)}{\mathrm{CC}_{0}\left(\mathrm{mg} \mathrm{l}^{-}\right.}$ & \% Biosorption \\
\hline 6.5 & 34.92 & $15 \mathrm{~h}$ & 14.4 & 41.1 & 34.92 & $15 \mathrm{~h}$ & 16.7 & 47.8 \\
\hline 7 & 49.85 & 15h & 33.7 & 67.5 & 49.85 & $15 \mathrm{~h}$ & 26.1 & 52.4 \\
\hline 7.5 & 54.22 & $15 \mathrm{~h}$ & 43.0 & 79.2 & 54.22 & $15 \mathrm{~h}$ & 38.7 & 71.3 \\
\hline 8 & 59.01 & $9 \mathrm{~h}$ & 50.3 & 85.2 & 59.01 & $9 \mathrm{~h}$ & 51.1 & 86.6 \\
\hline 8.5 & 62.39 & 9h & 54.6 & 87.5 & 62.39 & $12 \mathrm{~h}$ & 53.5 & 85.8 \\
\hline
\end{tabular}

Table 3. Effect of pH on biosorption of dye (reactive blue 214) by Spirulina subsalsa. and Scenedesmus ecornis $\left(50 \mathrm{mg} \mathrm{l}^{-1}, 30^{\circ} \mathrm{C}, 100 \mathrm{rpm}\right)$

\begin{tabular}{|c|c|c|c|c|c|c|c|c|}
\hline \multirow[b]{2}{*}{ pH } & \multicolumn{4}{|c|}{ Spirulina subsalsa (reactive blue 214) } & \multicolumn{4}{|c|}{ Scenedesmus ecornis (reactive blue 214) } \\
\hline & $\mathrm{C}_{0}\left(\mathrm{mg} \mathrm{l}^{-1}\right)$ & $\begin{array}{c}\text { Time } \\
\text { (hours) }\end{array}$ & $\mathrm{CC}_{0}\left(\mathrm{mgl}^{-1}\right)$ & \% Biosorption & $\mathrm{C}_{0}\left(\mathrm{mg} \mathrm{l}^{-1}\right)$ & $\begin{array}{c}\text { Time } \\
\text { (hours) }\end{array}$ & $\mathrm{CC}_{0}\left(\mathrm{mg} \mathrm{l}^{-}\right.$ & $\%$ Biosorption \\
\hline 6.5 & 47.54 & $15 \mathrm{~h}$ & 17.9 & 37.6 & 47.54 & $15 \mathrm{~h}$ & 18.4 & 38.7 \\
\hline 7 & 47.68 & 15h & 23.8 & 50.0 & 47.68 & 15h & 24.4 & 51.1 \\
\hline 7.5 & 48.07 & 15h & 26.0 & 54.0 & 48.07 & 15h & 28.8 & 59.9 \\
\hline 8 & 48.6 & $15 \mathrm{~h}$ & 39.8 & 81.9 & 48.6 & $15 \mathrm{~h}$ & 39.0 & 80.2 \\
\hline 8.5 & 49.27 & $12 \mathrm{~h}$ & 41.1 & 83.5 & 49.27 & $12 \mathrm{~h}$ & 42.6 & 86.4 \\
\hline
\end{tabular}

Table 4. Effect of pH on biosorption of dye (reactive orange 16) by Spirulina sunsalsa and Scenedesmus ecornis $\left(50 \mathrm{mg} \mathrm{l}-1,30^{\circ} \mathrm{C}, 100 \mathrm{rpm}\right)$

\begin{tabular}{|c|c|c|c|c|c|c|c|c|}
\hline \multirow[b]{2}{*}{ pH } & \multicolumn{4}{|c|}{ Spirulina subsalsa (reactive orange 16) } & \multicolumn{4}{|c|}{ Scenedesmus ecornis (reactive orange 16) } \\
\hline & $\begin{array}{c}\text { Co } \\
(\mathrm{mg} \mathrm{l-1})\end{array}$ & $\begin{array}{c}\text { Time } \\
\text { (hours) }\end{array}$ & $\begin{array}{c}\mathrm{CCO} \\
\text { (mgl-1) }\end{array}$ & $\%$ Biosorption & $\begin{array}{c}\mathrm{CO} \\
(\mathrm{mg} \mathrm{l} \mathbf{- 1})\end{array}$ & $\begin{array}{c}\text { Time } \\
\text { (hours) }\end{array}$ & $\begin{array}{c}\mathrm{CCO} \\
(\mathrm{mg} \mathrm{l-1})\end{array}$ & \% Biosorption \\
\hline 6.5 & 73.03 & $15 \mathrm{~h}$ & 9.3 & 12.8 & 73.03 & $15 \mathrm{~h}$ & 35.4 & 48.5 \\
\hline 7 & 73.26 & $15 \mathrm{~h}$ & 8.4 & 11.4 & 73.26 & $15 \mathrm{~h}$ & 44.0 & 60.1 \\
\hline 7.5 & 73.6 & $15 \mathrm{~h}$ & 9.1 & 12.4 & 73.6 & $15 \mathrm{~h}$ & 47.8 & 65.0 \\
\hline 8 & 74.06 & $15 \mathrm{~h}$ & 12.9 & $\mathbf{1 7 . 4}$ & 74.06 & $15 \mathrm{~h}$ & 51.0 & 68.8 \\
\hline 8.5 & 74.51 & $15 \mathrm{~h}$ & 12.7 & 17.0 & 74.51 & $15 \mathrm{~h}$ & 48.6 & \\
\hline
\end{tabular}


Table 5. Effect of pH on biosorption of dye (direct Red 254) by Spirulina sunsalsa and Scenedesmus ecornis $\left(50 \mathrm{mg} \mathrm{l}-1,30^{\circ} \mathrm{C}, 100 \mathrm{rpm}\right)$

\begin{tabular}{|c|c|c|c|c|c|c|c|c|}
\hline \multirow[b]{2}{*}{ pH } & \multicolumn{3}{|c|}{ Spirulina subsalsa (direct red 254) } & \multicolumn{5}{|c|}{ Scenedesmus ecornis (direct red 254) } \\
\hline & $\begin{array}{c}\text { C0 } \\
(\mathrm{mg} \mathrm{l-1}) \\
\end{array}$ & $\begin{array}{c}\text { Time } \\
\text { (hours) }\end{array}$ & $\begin{array}{c}\text { CC0 } \\
\text { (mgl-1) }\end{array}$ & \% Biosorption & $\begin{array}{c}\text { C0 } \\
(\mathrm{mg} \mathrm{l-1}) \\
\end{array}$ & $\begin{array}{c}\text { Time } \\
\text { (hours) }\end{array}$ & $\begin{array}{c}\mathrm{CCO} \\
(\mathrm{mg} \mathrm{l}-1) \\
\end{array}$ & \% Biosorption \\
\hline 6.5 & 50.37 & $15 \mathrm{~h}$ & 20.8 & 41.3 & 50.37 & $15 \mathrm{~h}$ & 17.8 & 35.3 \\
\hline 7 & 50.67 & $15 \mathrm{~h}$ & 22.5 & 44.5 & 50.67 & $15 \mathrm{~h}$ & 20.3 & 40.0 \\
\hline 7.5 & 50.98 & $15 \mathrm{~h}$ & 24.3 & 47.6 & 50.98 & $15 \mathrm{~h}$ & 20.7 & 40.7 \\
\hline 8 & 51.28 & $15 \mathrm{~h}$ & 26.5 & 51.6 & 51.28 & $15 \mathrm{~h}$ & 25.8 & 50.3 \\
\hline 8.5 & 51.58 & $15 \mathrm{~h}$ & 30.0 & 58.2 & 51.58 & $15 \mathrm{~h}$ & 23.5 & 45.6 \\
\hline
\end{tabular}

Effect of algal biomass on biosorption of Dyes by Spirulina subsalsa and Scenedesmus ecornis: The effect of different biomass (0.3, $0.6,0.9,1.2,1.5 \mathrm{~g} \mathrm{ml}^{-1}$ ) on biosorption of different dyes by Spirulina subsalsa and Scenedesmus ecornis were studied. In Figure 3 (a-j) Spirulina subsalsa and Scenedesmus ecornis recorded high adsorption of reactive yellow $(88.5 \%$ at 12 . hours, $87.7 \%$ at 9 . hours), reactive black $5(88.1 \%, 87 \%)$ at 12 .

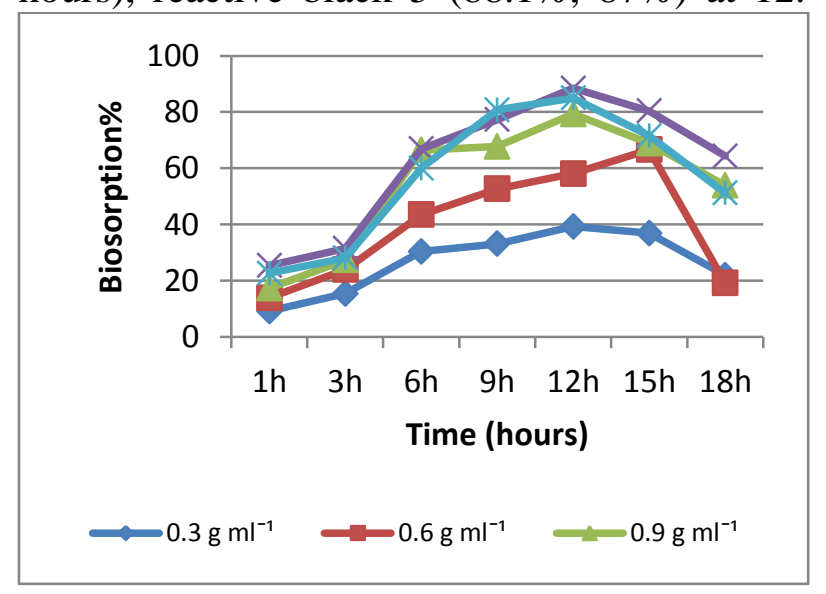

(a)

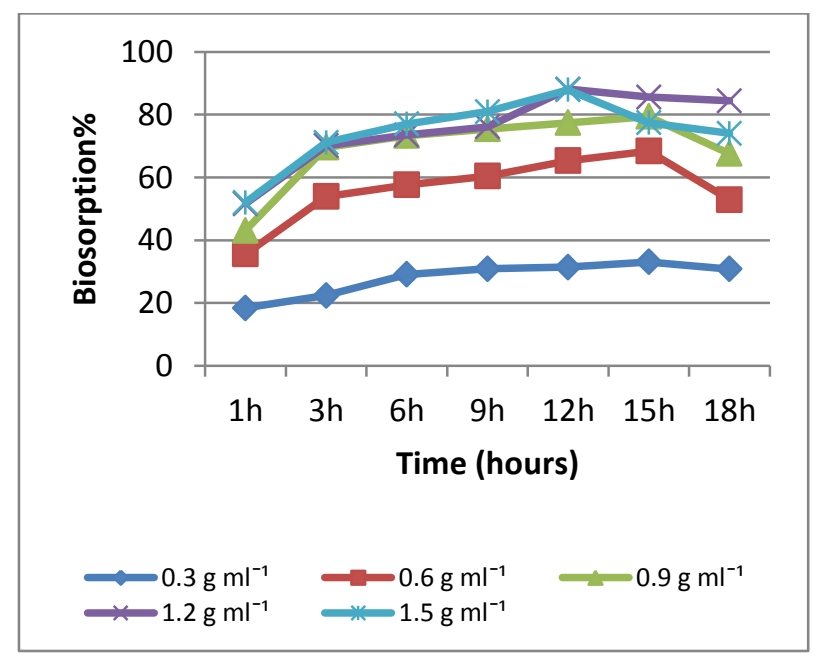

(c) hours, reactive blue 214 with $1.5 \mathrm{~g} \mathrm{ml}^{-1}$ $(83.3 \%, 86.8 \%)$ at 12 . hours, optimum adsorption of reactive black 5 and reactive orange 16 showed with biomass $1.2 \mathrm{~g} \mathrm{ml}^{-1}$ of Scenedesmus ecornis and for reactive yellow, reactive blue 214, direct red 254 was with biomass $1.5 \mathrm{~g} \mathrm{ml}^{-1}$. It was observed that biosorption percentage increased with increase in biomass.

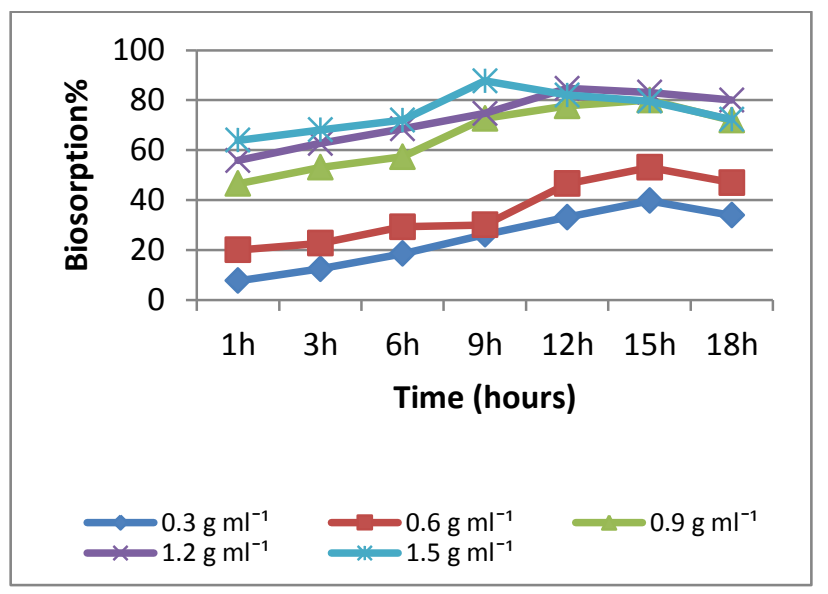

(b)

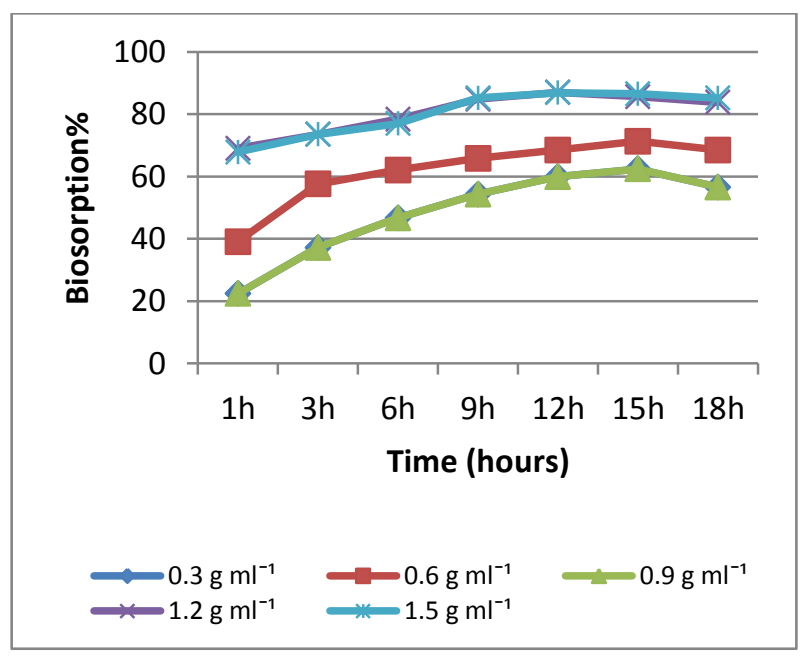

(d) 


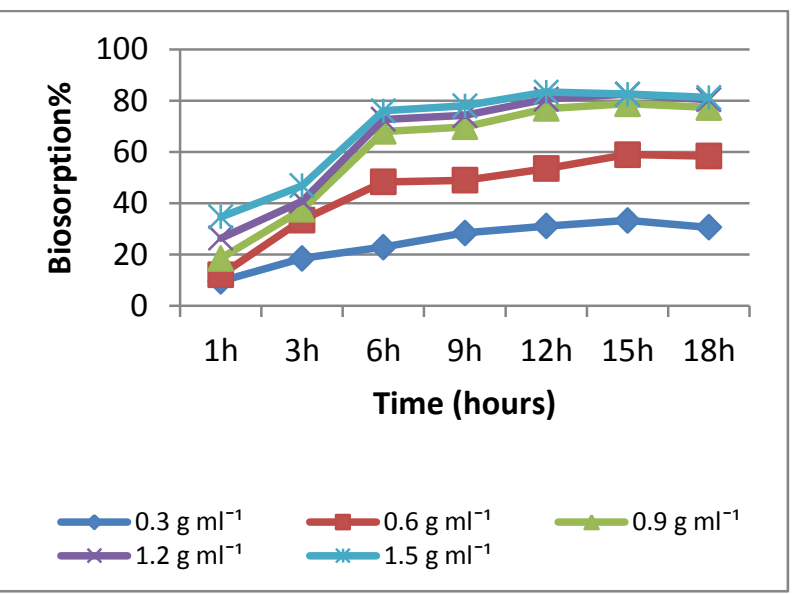

(e)

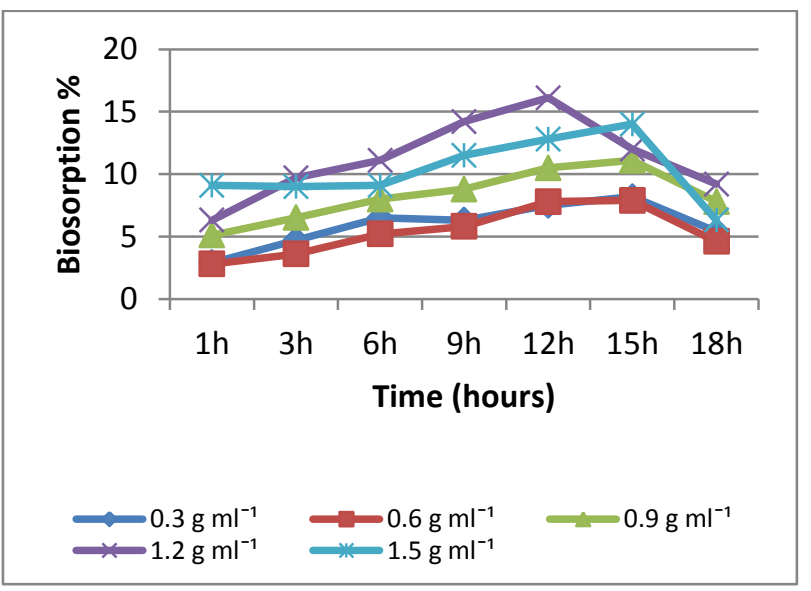

(g)

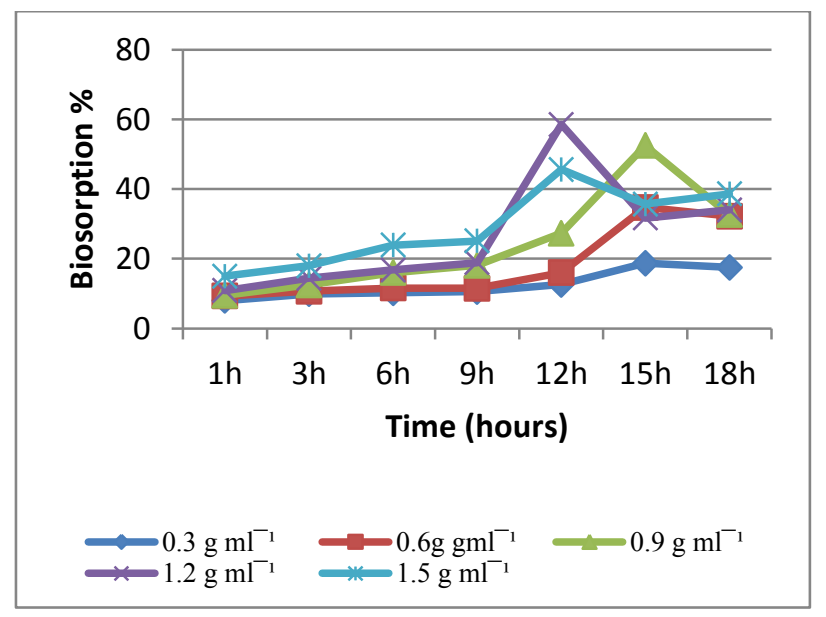

(i)

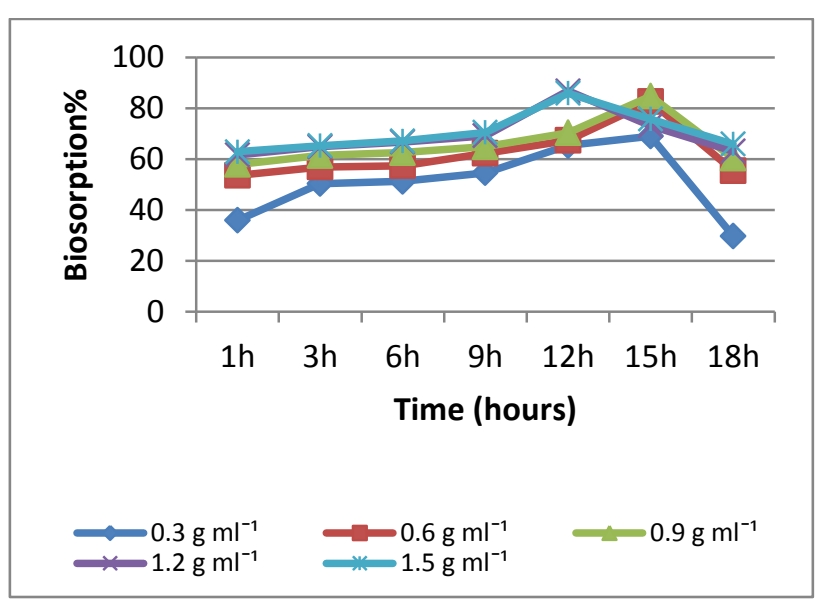

(f)

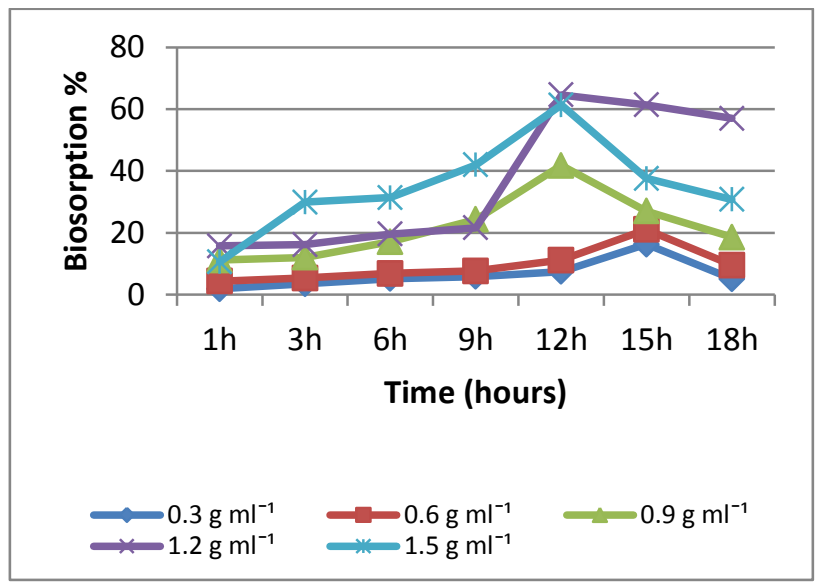

(h)

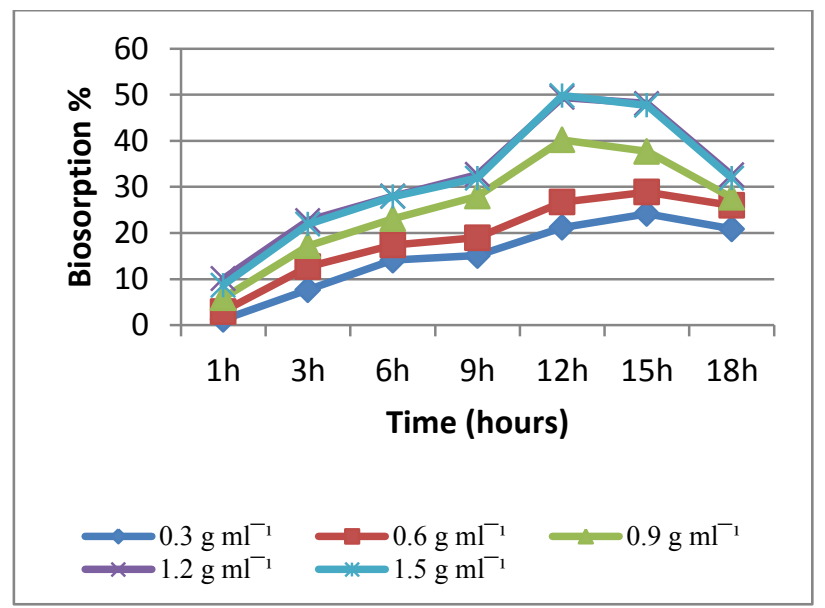

(j)

Fig. 3. Effect of biosorbent dosage on dye [(a,b) Reactive yellow, (c,d) Reactive black 5, (e,f) reactive Blue, (g,h) Reactive Orange 16, (i,j) Direct Red 254)] (50 mg l-1, 30 $\left.{ }^{\circ} \mathrm{C}, \mathrm{pH} \mathrm{8}, 100 \mathrm{rpm}\right)$ by (a, c, e, g, i) Spirulina subsalsa and (b, d, f, h, j) Scenedesmus ecornis

Effect of agitation speeds on biosorption of dyes by Spirulina subsalsa and Scenedesmus ecornis: To determine effect of agitation speed on dye biosorption a series of experiments at different degrees of agitation (zero rotation, 50, 100, 150 and $200 \mathrm{rpm}$ )) were undertaken and shown in Figure 4 (a-j) which indicates that the degree of agitation influences the sorption rate as the agitation speed increases from zero rotation to $200 \mathrm{rpm}$. 
Both strains Spirulina subsalsa and Scenedesmus ecornis showed optimum uptake at $150 \mathrm{rpm}$. The uptake of Reactive yellow was $(89.3 \%, 90.4 \%)$ at 9 hours, reactive black $5(88.7 \%, 88.3 \%)$ at 12 . hours, reactive Blue $214(86.1 \%$ at 15 hours, $86.9 \%$ at 12 . hours. By increasing of agitation to $200 \mathrm{rpm}$ the sorption rates showed differ to a quite small extent, indicating that the film thickness has insignificant effect when the agitation rate is higher than $200 \mathrm{rpm}$ and the weak binding dyes. Hence, an agitation rate of $150 \mathrm{rpm}$ was selected. This results same with (13) Indicated that the contact between biomass and dye solution is more effective at moderate agitation $(150 \mathrm{rpm})$. An increase in agitation speed of up to $150 \mathrm{rpm}$ could have facilitated proper contact between dye solution and biomass binding sites, thereby encouraging the effective transfer of sorbate ions to sorbent sites (8). The observed decrease in dye removal beyond $150 \mathrm{rpm}$ could be attributed to an increase in turbulence associated with the desorption of adsorbates in the solution and therefore an increase in the residual concentration of dyes (2).

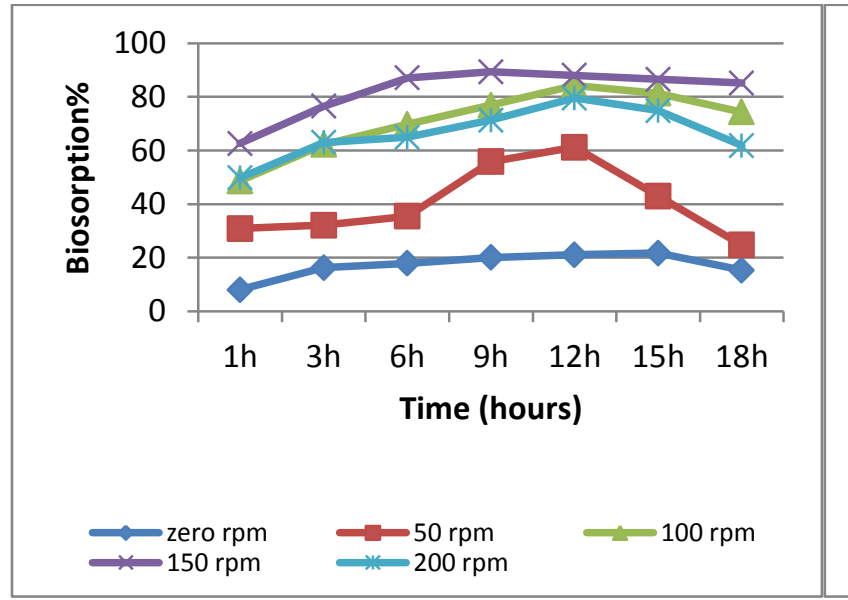

(a)

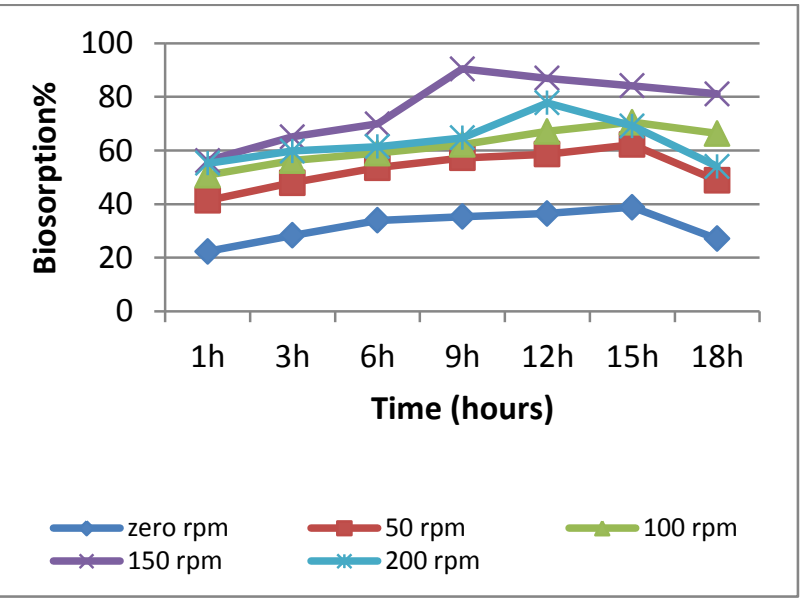

(b)

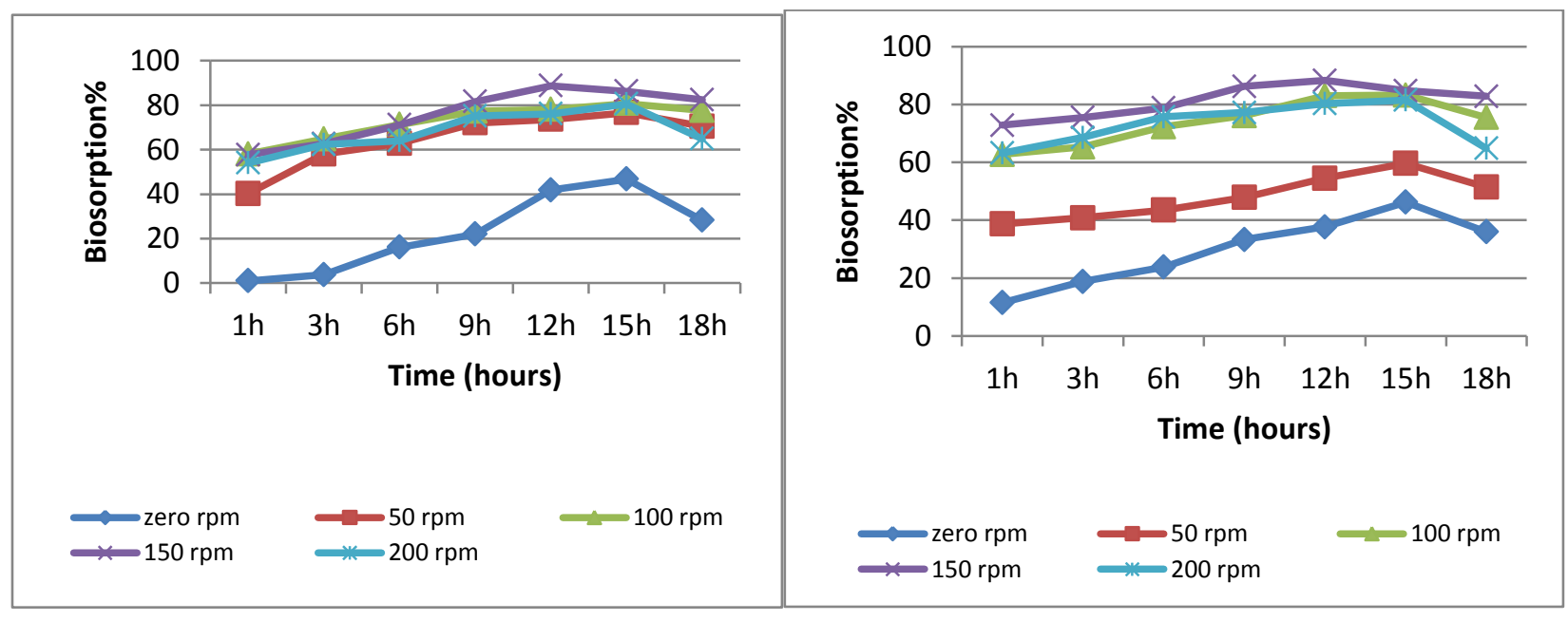

(c)

(d) 


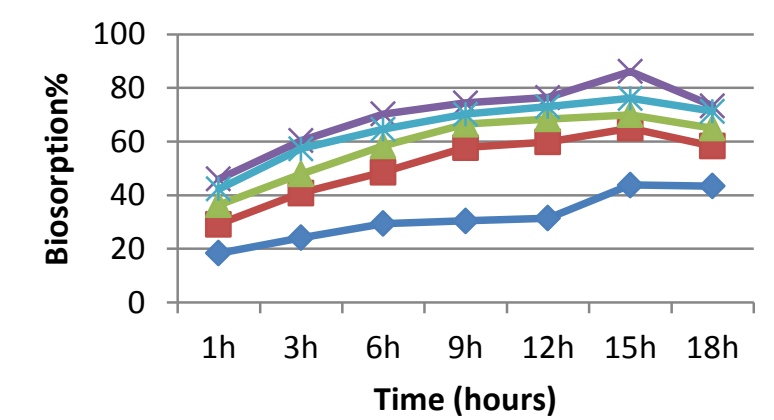

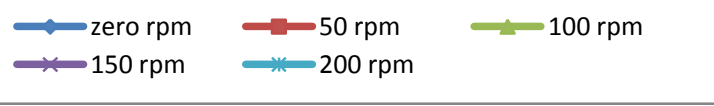

(e)

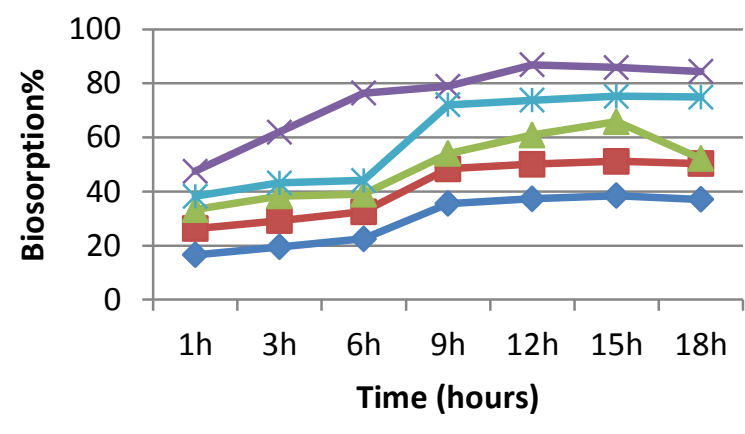

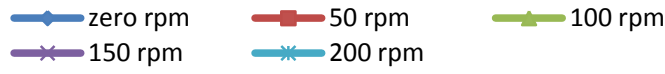

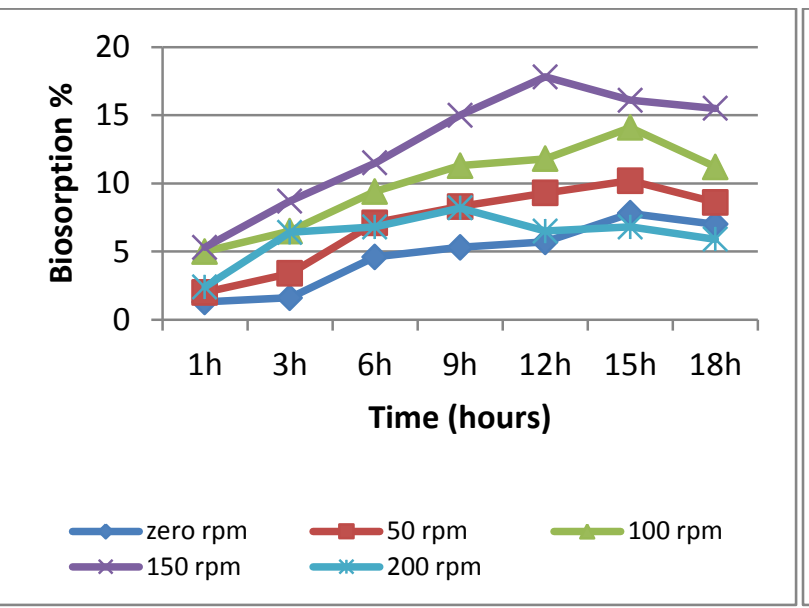

(g)

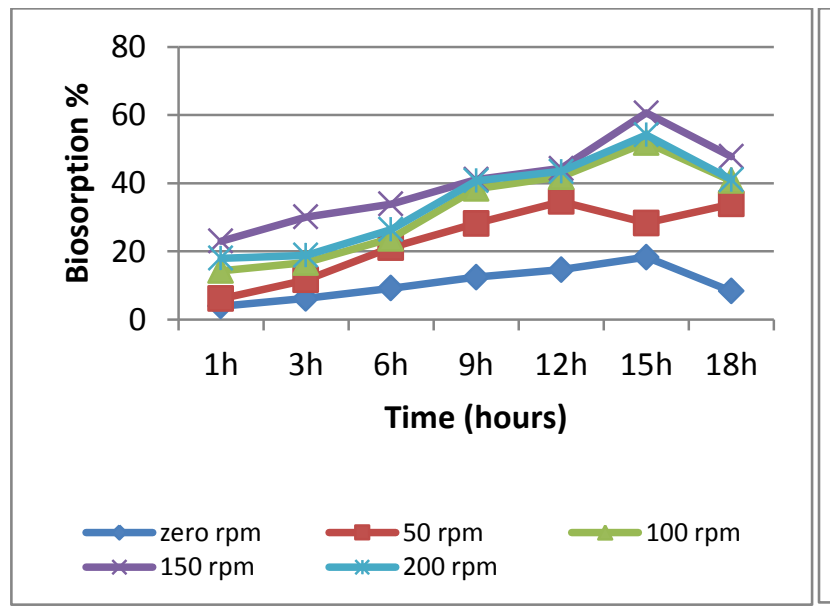

(i)

(f)

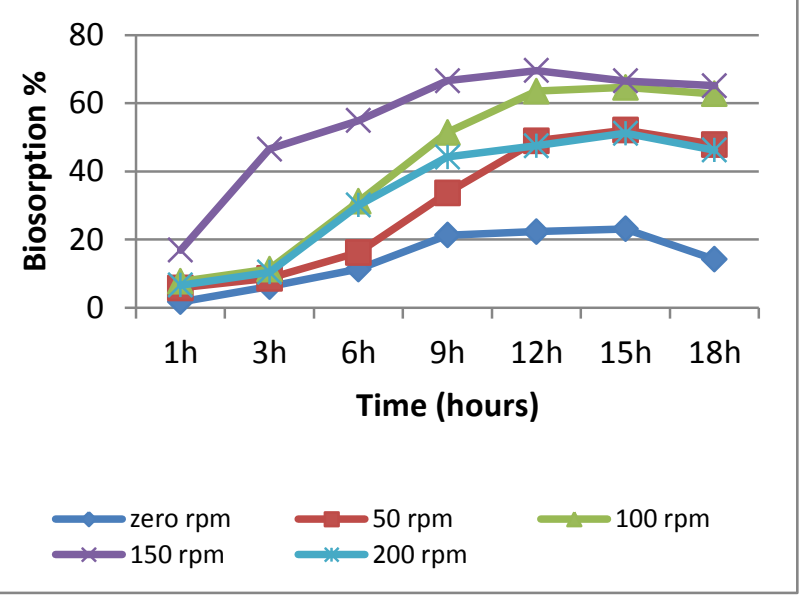

(h)

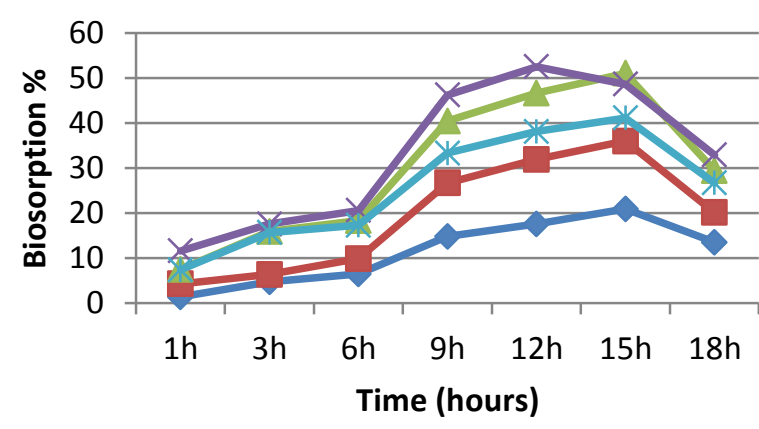

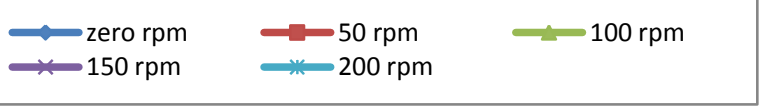

(j)

Fig. 4. Effect of agitation speed on biosorption of dye [(a,b) Reactive yellow, (c,d) Reactive black 5, (e,f) reactive Blue, (g,h) Reactive Orange 16, (i,j) Direct Red 254)] $\left(50 \mathrm{mg} \mathrm{l}^{-1}, 30^{\circ} \mathrm{C}\right.$, pH 8, dosage $1.2 \mathrm{~g} \mathrm{ml}^{-1}$ ) by (a, c, e, g, i) Spirulina subsalsa and (b, d, f, h, j) Scenedesmus ecornis 


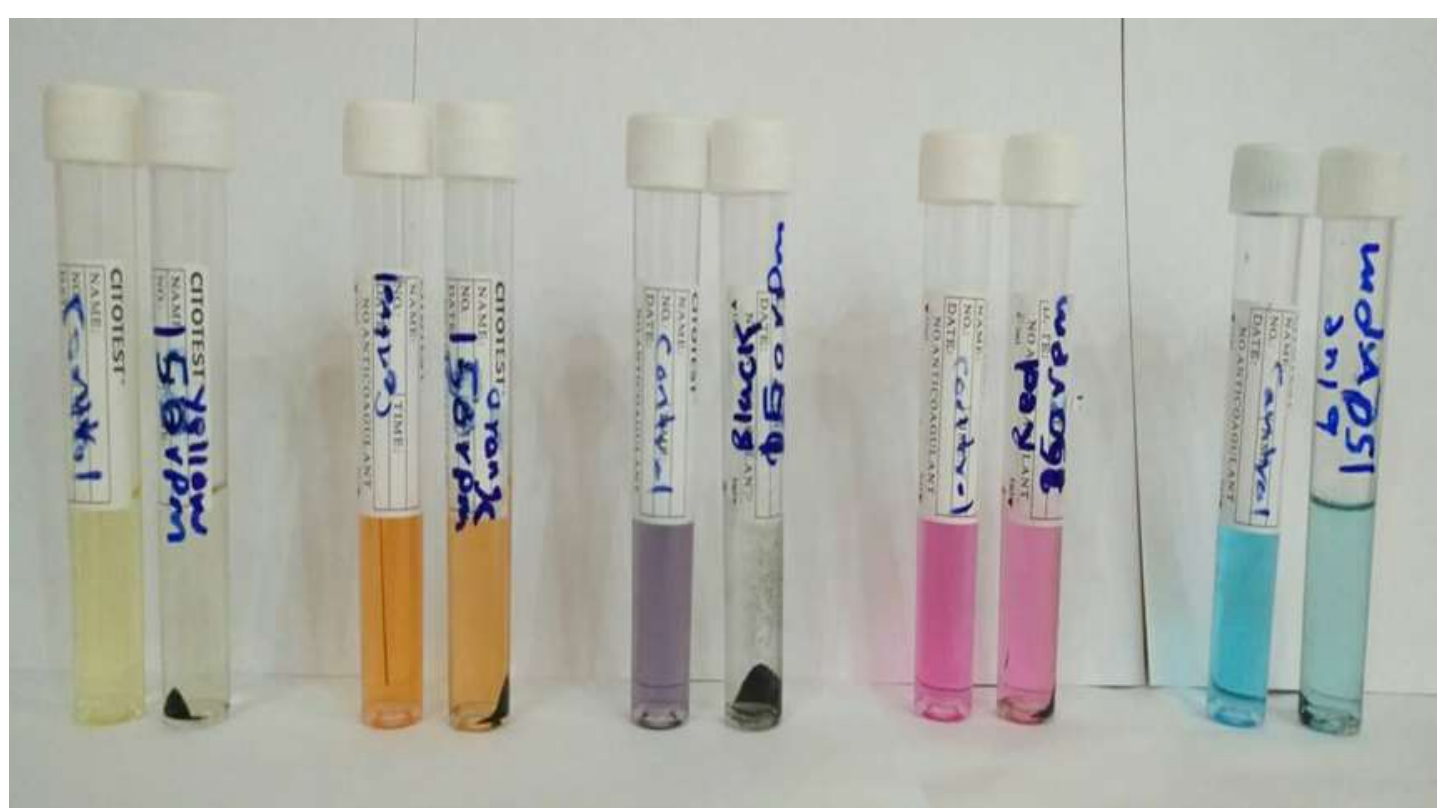

Fig. 5. Effect of agitation speed on biosorption of dye (reactive yellow, reactive orange 16, reactive black 5, direct red 254 and reactive blue 214) by Spirulina subsalsa compared with control without biomass

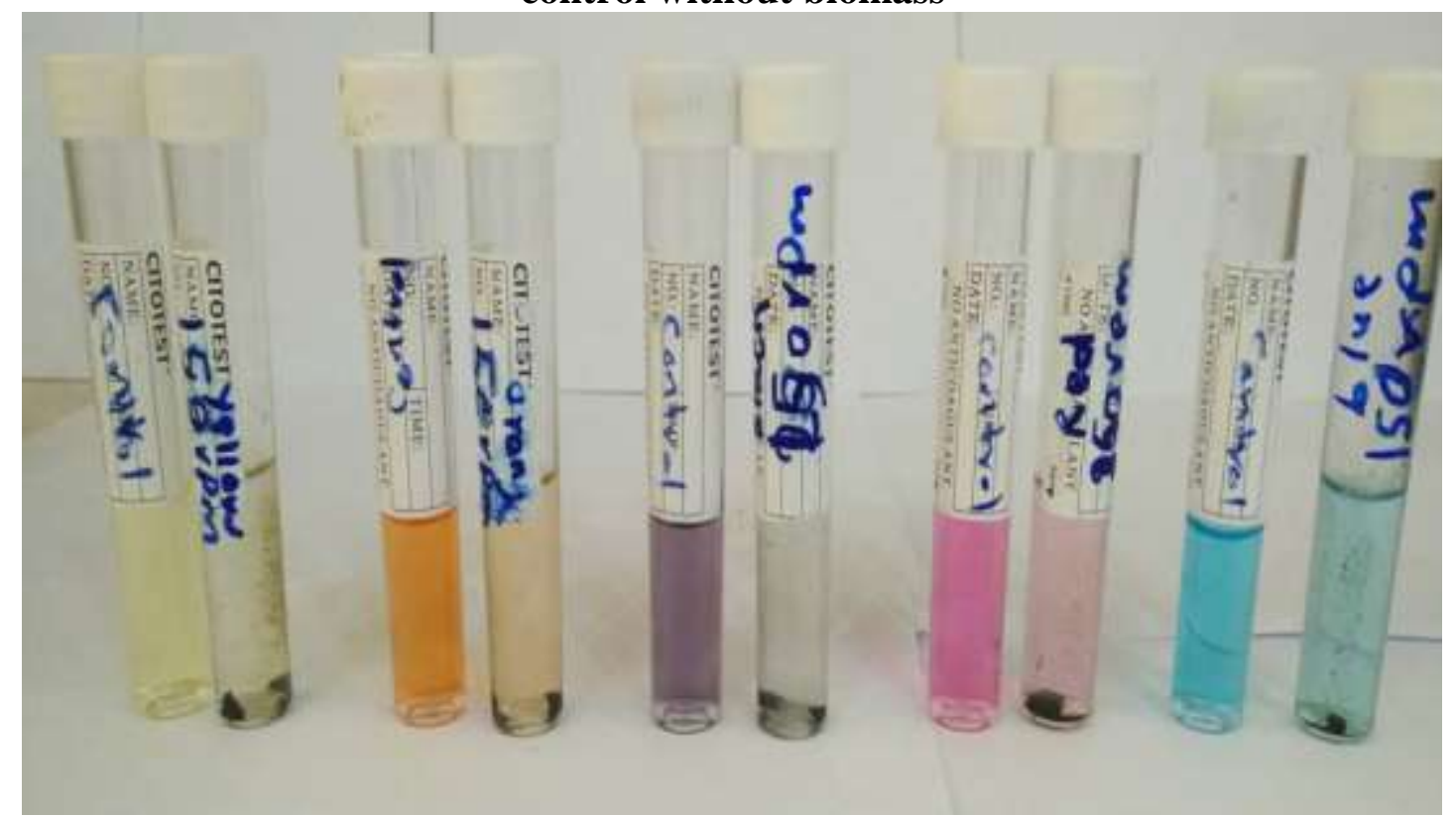

Fig. 6. Effect of agitation speed on biosorption of dye (reactive yellow, reactive orange 16, reactive black 5, direct red 254 and reactive blue 214) by Scenedesmus ecornis.

Fourier-transform infrared spectroscopy (FT-IR)characterization of microalgae cell wall:Fourier transformation infrared (FT-IR) spectroscopy was used in the study to identify and determine spectral features of Spirulina subsalsa and Scenedesmus ecornis surface characterization for Reactive yellow dye that showed optimum adsorption before and after dye biosorption. FTIR was carried out in order to investigate the functional groups of algal cell wall responsible for dye biosorption. The FT-IR spectral region was between (400-4000) $\mathrm{cm}^{-1}$ and (FT-IR) means Fourier transformation infrared spectrometer with high resolution. FT-IR spectra gives 10 chemical adsorption bands with 10 different frequencies before adsorption, at $3298 \mathrm{~cm}^{-1}, 2926 \mathrm{~cm}^{-1}$, $2873 \mathrm{~cm}^{-1}, 1654 \mathrm{~cm}^{-1}, 1541 \mathrm{~cm}^{-1}, 1456 \mathrm{~cm}^{-1}$, $1394 \mathrm{~cm}^{-1}, 1242 \mathrm{~cm}^{-1}, 1080 \mathrm{~cm}^{-1}$ and $524 \mathrm{~cm}^{-1}$. The FT-IR spectra of control cell (before dye adsorption) shows broad and prominent peaks at $3298 \mathrm{~cm}^{-1}$ which represents the stretching vibration of carbohydrates $(\mathrm{O}-\mathrm{H})$ group of the Spirulina subsalsa biomass (Figure 7). The peak at $2926 \mathrm{~cm}^{-1}$ assigned to $(\mathrm{C}-\mathrm{H})$ stretching of alkene. The peak between 1541-1456 $\mathrm{cm}^{-1}$ which represents the symmetric and asymmetric stretching of $(\mathrm{N}-\mathrm{O})$ group. After 
yellow dye the adsorption of pollution on the carboxylic functional group or hydroxyl group of protein of Spirulina subsalsa was increase science the band become broad due to H-band and shifting to the higher wave number or frequency. For Scenedesmus ecornis (FT-IR) gives 11 signal or chemical adsorption vibration for functional groups before adsorption by dye. Which are : $3313 \mathrm{~cm}^{-1}$, $2926 \mathrm{~cm}^{-1}, 2854 \mathrm{~cm}^{-1}, 1653 \mathrm{~cm}^{-1}, 1541 \mathrm{~cm}^{-1}$, $1456 \mathrm{~cm}^{-1}, 1394 \mathrm{~cm}^{-1}, 1238 \mathrm{~cm}^{-1}, 1080 \mathrm{~cm}^{-1}$, $1043 \mathrm{~cm}^{-1}, 545 \mathrm{~cm}^{-1}$ (Figure 8). The peak between 2926-2854 $\mathrm{cm}^{-1}$ represents the symmetric and asymmetric stretching for $(\mathrm{C}-$ H) $\mathrm{CH}_{2}$ lipid and carbohydrate. The peak between 1541-1456 which represents the $(\mathrm{N}-$ $\mathrm{H})$ bending protein amide. Where these chemical adsorption bands are shifted to the higher or lower frequency region depending on the how much adsorption occur after using Reactive yellow dye and rotating $150 \mathrm{rpm}$ and $\mathrm{pH} 8$ on the functional groups present in the Scenedesmus ecornis. $(4,20)$ showed that the FT-IR data of five functional groups were probably involved in the adsorption of the dye.

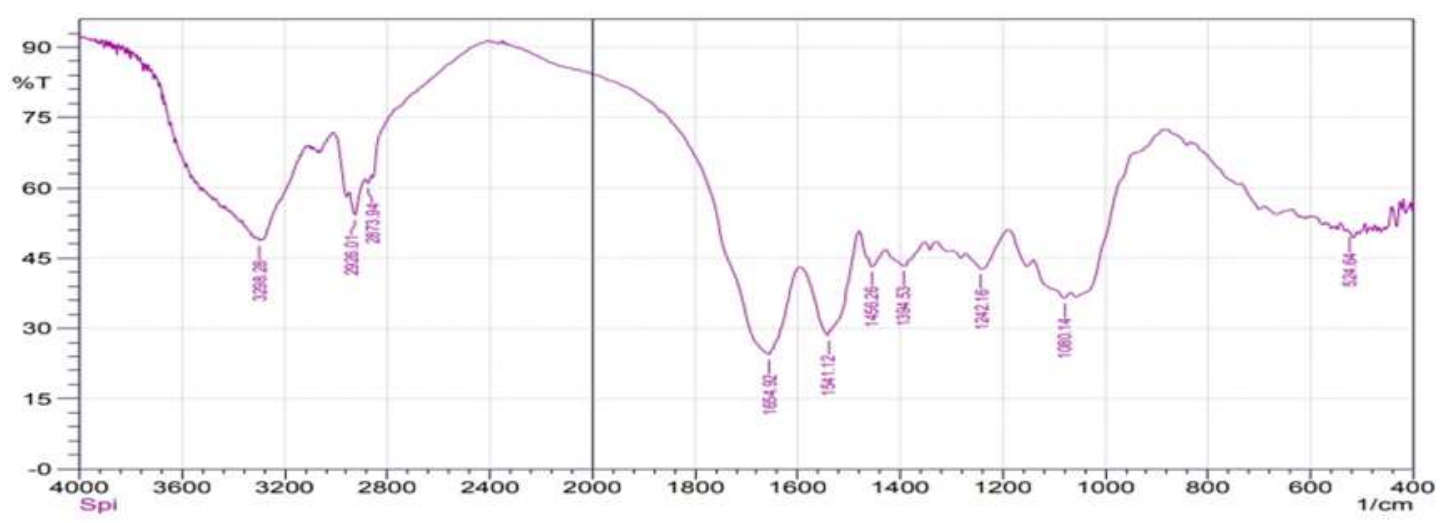

(b)

Fig. 7. FT-IR spectrum of Spirulina subsalsa (a) before and (b) after dye biosorption

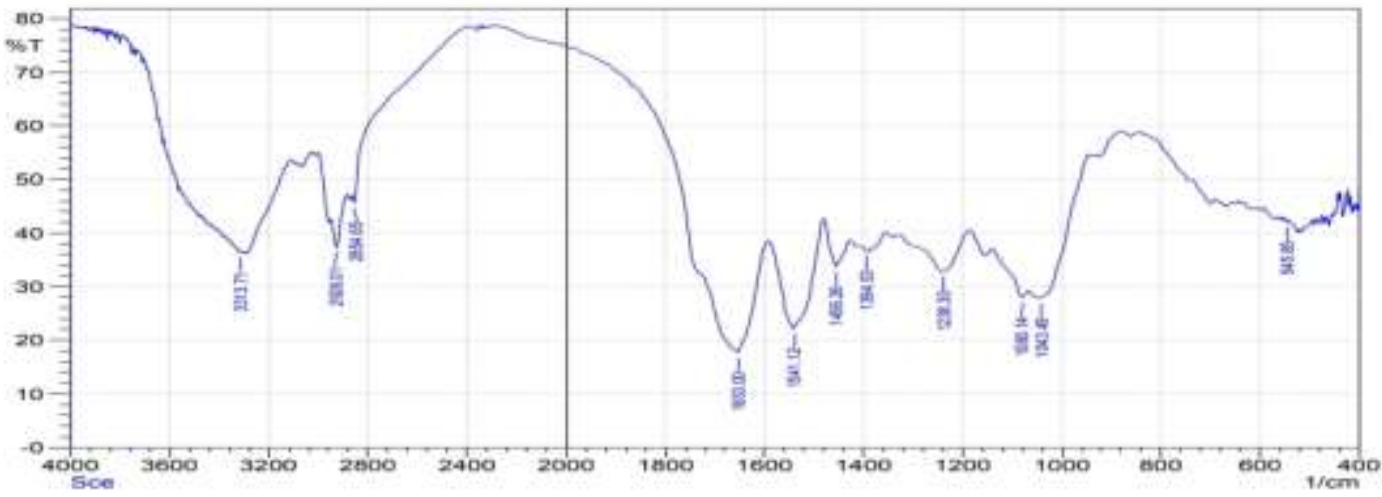

(a)

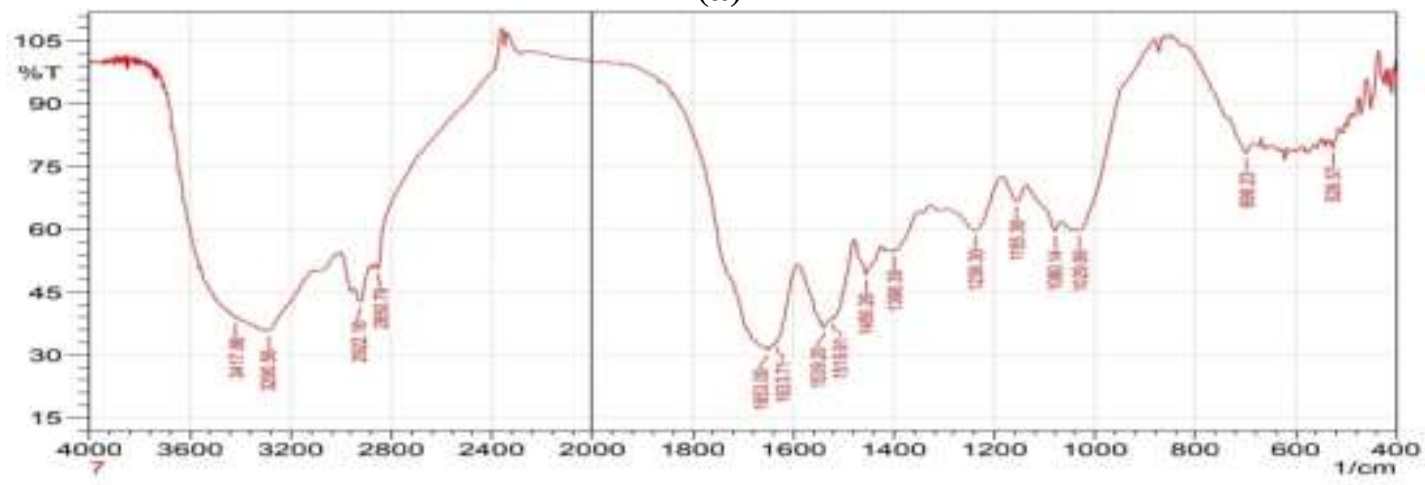

(b)

Fig. 8. FT-IR spectrum of Scenedesmus ecornis (a) before and (b) after dye biosorption 


\section{REFERENCES}

1. Abdulkareem, H.N. and A. I. Alwared. 2019. Immobilization dried mix of algae for copper removal. Iraqi Journal of Agricultural Sciences, 50(3):800- 808

2. Alam, M.Z. 2004. Biosorption of basic dyes using sewage treatment plant biosolids. Biotechnology, 3(2): 200-204

3. Allen, M. M. and R. Y. Stanier. 1968. Growth and division of some unicellular bluegreen algae. - Microbiology 51(2): 199-202

4. Al-Qaisi, M.R.Z., R.A. Abdul-Jabbar, and A.A. Al-Hussieny. 2019. Reduction of some heavy elements from polluted water using the biological adsorption technique by dry algae. Iraqi Journal of Agricultural Sciences, 50(4):1162-1173

5. Anwer, S.S. 2011. Biosorption of dyes by cyanobacteria isolated from Kanii Bee. Kirkuk University Journal, 3(6), Ist. Conf, Biology

6. Anwer, S.S. and S. Merkhan. 2013. Removal of different dyes by Pseudomonas fluorescens. Journal of Life Sciences, 7(1), p.51

7. Asfaram, A., M. Ghaedi, G.R. Ghezelbash and F. Pepe. 2017. Application of experimental design and derivative spectrophotometry methods in optimization and analysis of biosorption of binary mixtures of basic dyes from aqueous solutions. Ecotoxicology and environmental safety, 139: 219-227

8. Asma, D., S. Kahraman, S. Cing and O. Yesilada. 2006. Adsorptive removal of textile dyes from aqueous solutions by dead fungal biomass. Journal of basic microbiology, 46(1): 3-9

9. Bule, M.H., I. Ahmed, F. Maqbool, M. Bilal, and H.M.N. Iqbal. 2018. Microalgae as a source of high-value bioactive compounds. Front. Biosci.(Sch. Ed.), 10: $197-$ 216

10. Bulgariu, D. and L. Bulgariu. 2012. Equilibrium and kinetics studies of heavy metal ions biosorption on green algae waste biomass. Bioresource technology, 103(1): 489493

11. Bulgariu, L. and D. Bulgariu. 2017. Sustainable utilization of marine algae biomass for environmental bioremediation. In Prospects and Challenges in Algal Biotechnology; Springer: Singapore: 179-217
12. Dönmez, G. and Z. Aksu. 2002. Removal of chromium (VI) from saline wastewaters by Dunaliella biochemistry, 38(5): 751-762

13. Farah, J.Y. and N.S. El-Gendy. 2007. Performance and kinetic studies on biosorption of Astrazon Blue dye by dried biomass of Baker's yeast as a low cost biosorbent. Bioscience Biotechnology Research Asia, 4: 359-370

14. Gadd, G.M. 2009. Biosorption: critical review of scientific rationale, environmental importance and significance for pollution treatment. Journal of Chemical Technology and Biotechnology: International Research in Process, Environmental and Clean Technology, 84(1): 13-28

15. Ghaly, A.E., R. Ananthashankar, M.V.V.R. Alhattab, and V.V. Ramakrishnan. 2014. Production, characterization and treatment of textile effluents: a critical review. J Chem Eng Process Technol, 5(1): 1000182

16. Guler, U.A., M. Ersan, E. Tuncel, and F. Dügenci. 2016. Mono and simultaneous removal of crystal violet and safranin dyes from aqueous solutions by HDTMA-modified Spirulina sp. Process Safety and Environmental Protection, 99: 194-206

17. Gulnaz, O., A. Kaya, F. Matyar, and B. Arikan. 2004. Sorption of basic dyes from aqueous solution by activated sludge. Journal of hazardous materials, 108(3): 183-188

18. Iqbal, M. and A. Saeed. 2007. Biosorption of reactive dye by loofa sponge-immobilized fungal biomass of Phanerochaete chrysosporium. Process Biochemistry, 42(7): 1160-1164

19. Khalaf, M.A. 2008. Biosorption of reactive dye from textile wastewater by non-viable biomass of Aspergillus niger and Spirogyra sp. Bioresource Technology, 99(14): 66316634

20. Kumar, S., A.S. Ahluwalia, M.U. Charaya and S. Kaur. 2019. Adsorption of Orange-G dye by the dried powdered biomass of Chlorella vulgaris beijerinck. current science, 116(4): 604

21. Marungrueng, K. and P. Pavasant. 2006. Removal of basic dye (Astrazon Blue FGRL) using macroalga Caulerpa lentillifera. Journal 
of Environmental Management, 78(3): 268274

22. Omer H, A. El-gendy, K. Al-ahmari. 2018. Bioremoval of toxic dye by using different marine macroalgae. Turkish Journal of Botany, 42: 15-27

23. Oswaled, W. 1988. Microalgae and Waste Water Treatment In: Borowitizka MA and Borowitizka LJ. - Microalgae Biotechnology. Cambridge University press, Cambridge: $305-$ 328

24. Ozbay, N., A.S. Yargic, M.F. Gozukizil, and E. Onal. 2015. The Comparative Study on Decolorization of Remazol Yellow Dye from Aqueous Solutions by Biosorption, Fenton and Photo-Fenton Processes

25. Rashid, F.H., A.A. Taha, and N.J. Hameed. 2019. Study of toxic heavy metal removal by different chitosan/hyacinths plant composite. Iraqi Journal of Agricultural Sciences, 50(5):1416-1424

26. Sadettin S, and G. Donmez. 2007. Simultaneous Bioaccumulation of reactive dye and chromium(VI) by using thermophil Phormidium sp. Enzyme and Microbial Technology. 41(1):175-180

27. Shah, V., N. Garg, and D. Madamwar. 2001. An integrated process of textile dye removal and hydrogen evolution using cyanobacterium, Phormidium valderianum 28. Yusra, S. and H.N. Bhatti. 2010. Factors affecting biosorption of direct dyes from aqueous solution. Asian Journal of Chemistry, 22(9): 6625-6639. 